\title{
Guidelines for the use of NBCA in vascular embolization devised by the Committee of Practice Guidelines of the Japanese Society of Interventional Radiology (CGJSIR), 2012 edition
}

\author{
Yoshito Takeuchi $\cdot$ Hiroyuki Morishita $\cdot$ Yozo Sato $\cdot$ Shingo Hamaguchi $\cdot$ Noriaki Sakamoto $\cdot$ \\ Hiroyuki Tokue $\cdot$ Takafumi Yonemitsu $\cdot$ Kenji Murakami $\cdot$ Hiroyasu Fujiwara $\cdot$ Keitaro Sofue $\cdot$ \\ Toshi Abe $\cdot$ Hideyuki Higashihara $\cdot$ Yasuo Nakajima $\cdot$ Morio Sato
}

Received: 25 February 2014/ Accepted: 29 April 2014/Published online: 3 June 2014

(C) Japan Radiological Society 2014

\begin{abstract}
Cyanoacrylates are a group of fast-acting adhesives. They form low viscosity liquids in the monomer state and instantly polymerize to become adhesive upon contact with ionic substances. Since the 1950s, they have been used around the world for industrial and household purposes. $N$-butyl cyanoacrylate (NBCA) is a cyanoacrylate that is commonly used for medical care, and the closure of skin wounds with NBCA has been found to promote hemostasis. However, in Japan, the intravascular injection of NBCA is considered to be off-label use, except during the treatment of gastric varices under endoscopy. The use
\end{abstract}

Y. Takeuchi $(\bowtie)$

Department of Radiology, North Medical Center, Kyoto

Prefectural University of Medicine, 481, Otokoyama,

Yosanocho, Yosagun, Kyoto 629-2261, Japan

e-mail: yotake62@qg8.so-net.ne.jp

Y. Takeuchi $\cdot$ H. Morishita $\cdot$ Y. Sato $\cdot$ S. Hamaguchi $\cdot$

N. Sakamoto - H. Tokue - T. Yonemitsu - K. Murakami ·

H. Fujiwara · K. Sofue

The Panel of Practice Guidelines for the Use of NBCA in

Embolotherapy (PGNBCA panel), Kyoto, Japan

Y. Takeuchi

The Practice Guidelines for the Use of Embolic Materials Required for Special Vascular Care Committee (PGERSCC),

Kyoto, Japan

H. Morishita

Department of Diagnostic Radiology, Japanese Red Cross Kyoto

Daiichi Hospital, Kyoto, Japan

Y. Sato

Department of Diagnostic and Interventional Radiology, Aichi

Cancer Center Hospital, Nagoya, Japan

S. Hamaguchi · K. Murakami · Y. Nakajima

Department of Radiology, St. Marianna University School of

Medicine, Kawasaki, Japan of NBCA in embolotherapy is considered when the target vessels cannot be cannulated superselectively, for vascular diseases that require long segments of the target vessel to be embolized, or for patients in a hypocoagulable state. NBCA-based embolotherapy can be used to treat vascular malformations, acute hemorrhaging, tumors, and venous disease. The complications associated with NBCA-based embolotherapy include tissue ischemia, hemorrhaging, systemic or local reactions, and catheter adhesion to blood vessels. NBCA is mixed with Lipiodol to make it radiopaque and to adjust its polymerization time. Since there

\author{
N. Sakamoto \\ Department of Radiology, Tenri Hospital, Tenri, Japan \\ H. Tokue \\ Department of Diagnostic Radiology and Nuclear Medicine, \\ Gunma University Graduate School of Medicine, Maebashi, \\ Japan \\ T. Yonemitsu \\ Department of Emergency and Critical Care Medicine, \\ Wakayama Medical University, Wakayama, Japan \\ H. Fujiwara \\ Department of Radiology, Okayama University Medical School, \\ Okayama, Japan \\ K. Sofue \\ Department of Radiology, Kobe University, Graduate School of \\ Medicine, Kobe, Japan \\ T. Abe \\ Department of Radiology, Kurume University School of \\ Medicine, Kurume, Japan \\ T. Abe $\cdot$ H. Higashihara \\ The Review Board of the Practice Guidelines for the Use of \\ NBCA in Embolotherapy (RBNBCA), Kurume, Japan
}


are various technical aspects to performing NBCA-based embolotherapy safely, it should be carried out by, or with the assistance of, proficient interventional radiologists.

Keywords $N$-Butyl cyanoacrylate - Embolization · Indication · Complication · Lipiodol

\section{Introduction}

The Japan Society of Interventional Radiology (JSIR) is involved in developing and encouraging the widespread use of interventional radiological (IR) treatments in Japan. Accordingly, the Committee of Practice Guidelines of the Japanese Society of Interventional Radiology (CGJSIR) was established in May 2009 and began to devise practical guidelines for the standardization of IR treatments in Japan. Among the various IR treatments, vascular embolization is performed most often. It is used to control tumors, stop acute hemorrhaging in emergency medical care, and manage other conditions and diseases. Various materials such as metallic coils, gelatin sponges, cyanoacrylates, and ethanol have been employed for vascular embolization. However, apart from metallic coils and some gelatin sponge products, no other embolic materials have been approved for intravascular use. Since n-butyl cyanoacrylate (NBCA) and other embolic materials are considered to be necessary for certain vascular procedures even though they are not approved for vascular use, they are used under the supervision of interventional radiologists. Histoacryl (B. Braun Aesculap, Tokyo, Japan) is an NBCA product that is commercially available in Japan. In April 2008, the JSIR produced 'a statement regarding the embolic materials required for special vascular care', which refers to their indications, usage, and complications [1]. In October 2010, the CGJSIR formed the Practice Guidelines for the Use of Embolic Materials Required for Special Vascular Care Committee (PGERSCC) in order to devise guidelines for the use of gelatin sponge, NBCA, and ethanol because they have been found to be extremely useful in clinical practice, even though they have not been approved for vascular use. The Panel of Practice Guidelines for the Use of NBCA in Embolotherapy (PGNBCA panel) and the Review Board of Practice Guidelines for the Use of NBCA

H. Higashihara

Department of Radiology, Fukuoka University Chikushi

Hospital, Chikushi, Fukuoka, Japan

Y. Nakajima $\cdot$ M. Sato

The Committee of Practice Guidelines of the Japanese Society of Interventional Radiology (CGJSIR), Kawasaki, Japan

M. Sato

Department of Radiology, Wakayama Medical University,

Wakayama, Japan in Embolotherapy (RBNBCA) have since been launched by the PGERSCC. In the present article, the authors describe the current consensus regarding the use of NBCA for vascular embolization in Japan, and critically evaluate associated experimental and clinical reports.

\section{Purpose}

The purpose of the guidelines outlined below is to describe the current consensus regarding, and appropriate practical procedures for, transcatheter vascular embolization using NBCA. The guidelines devised by the CGJSIR aim to facilitate decision-making regarding IR treatments in clinical practice. Thus, they aim to be practical or technical in nature and to supplement the guidelines devised by other medical societies dealing with specific diseases or organs. Hopefully, the guidelines will ensure that transcatheter vascular embolization using NBCA is performed in an appropriate and safe manner and improve the relationships between medical staff and their patients. Furthermore, the guidelines should make it easier for operators to perform vascular embolization using NBCA. It should be noted that whilst the administrative board and guidelines committee of the JSIR have responsibility for producing the guidelines, operators are responsible for their application and should always take the patient's condition and the institutional situation into account. As a general rule, these guidelines are based on scientific evidence. When insufficient evidence was available for a particular recommendation, the recommendation was graded using a previously described classification system (see the "Recommendations and comments" section), and comments outlining the rationale for the recommendation in more detail have been added. Many kinds of materials are used for transcatheter vascular embolization. Operators should choose the most appropriate embolic materials based on the patient's situation and the clinical conditions. NBCA can be employed for vascular embolization; however, its usage has not been standardized. These guidelines represent the current consensus and are not intended to be used as a strict set of instructions that would limit doctors' decision-making power; i.e., the final clinical decision is left to the discretion of the treating physician.

\section{Basic approach}

Clinical questions (CQ) setting

The PGNBCA are based on CQ that might arise during vascular embolization using NBCA. Scientific evidence regarding vascular embolization using NBCA is limited 
Fig. 1 Flow diagram of the literature retrieval process

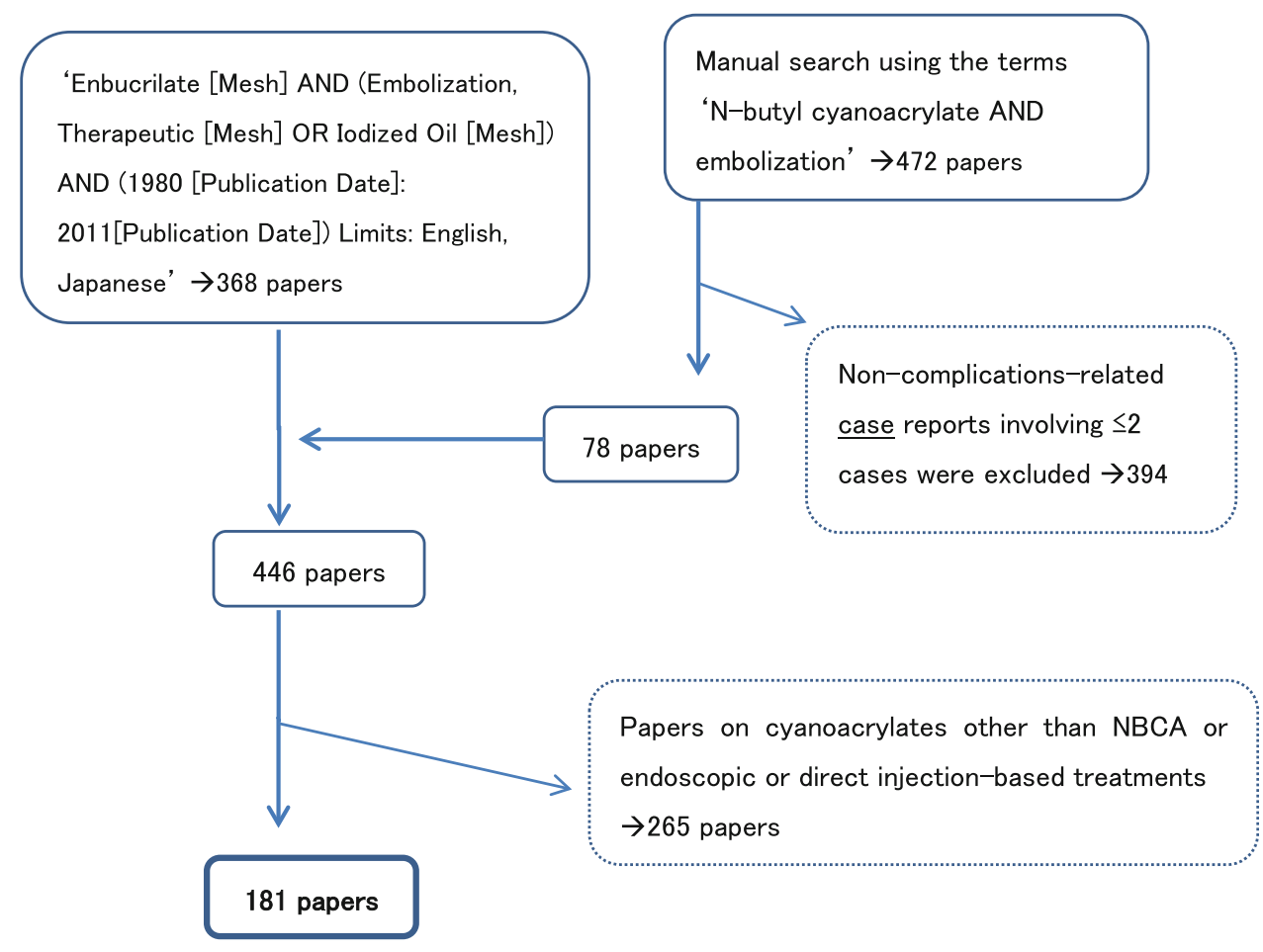

Table 1 Evidence level setting (Minds classification)

I: Meta-analysis by randomized controlled trials (RCT)

II: More than one RCT

III: Non-randomized control trials

IVa: Analytical epidemiologic study (cohort study)

IVb: Analytical epidemiologic study (case control study, cross sectional study)

V: Descriptive epidemiology (case report, case series)

VI: Expert opinion and personal expert committee that is not based on patient data

because most previous reports about the topic were case reports or described case series. The literature was reviewed by searching the PubMed database using keywords based on the PECO (patient, exposure, comparison, and outcome) parameters. First, 368 studies were obtained using the following keywords: 'Enbucrilate [Mesh] AND (Embolization, Therapeutic [Mesh] OR Iodized Oil [Mesh]) AND (1980 [Publication Date]: 2011 [Publication Date]) Limits: English, Japanese'. Subsequently, 472 reports were collected through an exhaustive manual search using " $N$-butyl cyanoacrylate AND embolization" as keywords; however, non-complications-related case reports involving $\leq 2$ cases were excluded. As a result, the remaining 78 reports were included. Finally, we adopted 181 papers from among these 446 reports, after excluding 265 papers on cyanoacrylates other than NBCA or endoscopic or direct injection-based treatments (Fig. 1).
Structured abstracts and evidence level setting

The panel and collaborative members critically reviewed the 181 abovementioned publications and created structured abstracts for them. In order to avoid bias in the interpretation of the papers or simple misreading, the structured abstracts were peer reviewed by another member of the committee. With respect to the examined papers, we classified the level of evidence provided in each paper according to the taxonomic system for structured abstracts produced by the Minds medical literature evaluation committee (Table 1) [2].

\section{Recommendations and comments}

We have provided answers to each CQ and added comments from the guidelines committee regarding the use of NBCA for vascular embolization. The council of the PGNBCA panel has also graded each recommendation according to the classification system described in Table 2. This classification system was also used to grade the recommendations provided in the stroke treatment guidelines developed by the Japan Stroke Society (2009 edition) [3]. In cases in which a recommendation was based on limited scientific evidence, the associated treatment was classified as "a treatment that might be considered,"which is used in the abovementioned stroke treatment guidelines, rather than "a treatment that is encouraged,"which is described in the Minds recommendation grading system, in 
Table 2 Recommended grade (modified from the literature 3)

\begin{tabular}{ll}
$\begin{array}{l}\text { Recommended } \\
\text { grade }\end{array}$ & Definition \\
\hline A & $\begin{array}{c}\text { Treatment that is strongly recommended } \\
\text { performing because of robust scientific evidence } \\
\text { Treatment that is recommended performing } \\
\text { because of enough scientific evidence }\end{array}$ \\
C1 & $\begin{array}{l}\text { Treatment that may be considered performing, but } \\
\text { there is not enough evidence }\end{array}$ \\
C2 & $\begin{array}{c}\text { Treatment that is suggested not performing because } \\
\text { there is no scientific basis }\end{array}$ \\
D & $\begin{array}{c}\text { Treatment that is suggested not performing because } \\
\text { of scientific evidence showing invalidity or } \\
\text { toxicity }\end{array}$ \\
\end{tabular}

consideration of the fact that the intravascular administration of NBCA is contraindicated at present. In addition, recommendation grades are not provided for the responses to the CQ about the effects or mechanism of action of NBCA or those to the CQ about NBCA's complications, but the information provided in these responses is important, as it helps operators to understand the properties of NBCA before using it for vascular embolization.

NBCA is used for vascular embolization at the discretion of operators. In line with this, CQ were selected with a view to enabling interventional radiologists to access information regarding treatment outcomes and complications, which are needed to examine the applicability of vascular embolization with NBCA, or information regarding necessary or safe treatment techniques. At present, there is insufficient information about vascular embolization using NBCA because it can be used to treat a heterogeneous range of diseases, and vascular embolization is often performed in the emergency setting. Therefore, the recommendation grades were determined after discussing the most important issues in the medical setting and obtaining the PGNBCA panel's consensus. Accordingly, the recommendation grades are not always consistent with the level of evidence that supports them. It is necessary for physicians to explain appropriate alternative treatment choices to patients and their families if they do not agree with the recommended methods. Physicians should consult interventional radiologists or transport candidates for vascular embolization using NBCA to another facility when it cannot be performed at their own facility. Providing the abovementioned approach is adhered to, alternative treatments are acceptable.

The comments included in the general descriptions are intended to make it easier for operators to understand the issues associated with each CQ. They should be regarded as references that facilitate the examination of CQ-related problems. The specific comments about each CQ were

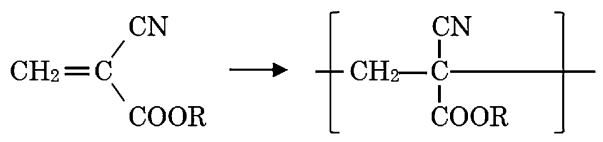

Fig. 2 Chemical structure of cyanoacrylates. The monomer (left) polymerizes immediately upon contact with an ionic substance (right). ' $R$ ' indicates an alkyl group (e.g., the $n$-butyl group in NBCA)

Table 3 Type of cyanoacrylates (modified from the literature 5)

\begin{tabular}{lll}
\hline Type of CA & Characteristics & Usage \\
\hline Methyl CA & Strong, hard & Metals \\
Ethyl CA & Strong, hard & Metals \\
Methoxy ethyl CA & Odorless & Metals, elastic, rubber, \\
& & cosmetics \\
Butyl CA (IBCA, & Elastic, & Metals, plastic, rubber, \\
NBCA) & odorless & cosmetics, medical \\
Octyl CA & Elastic, & Metals, plastic, rubber, \\
& odorless & cosmetics, medical, \\
& & dental \\
\hline
\end{tabular}

$C A$ cyanoacrylate, IBCA iso-butyl cyanoacrylate, NBCA $N$-butyl cyanoacrylate

critically appraised by all of the authors before being finally approved via consensual decision making. These guidelines are subject to revision whenever new evidence arises, new treatment methods are established, or social conditions change. Please contact the JSIR Office if you wish to propose CQ for inclusion in the guidelines, or have written or read articles that the JSIR members and/or guideline users might find useful. These guidelines were first published on the website of the JSIR in December 2012 (http://www.jsivr.jp/guideline/guidelineNBCA.html).

\section{General comments}

\section{Cyanoacrylates}

Cyanoacrylates (CA) are instantaneous adhesives that have been used around the world in the industrial, domestic, and medical settings since 1957. CA-based glues instantaneously adhere firmly to most kinds of material at room temperature and have been used in various fields. The polymerization of $\mathrm{CA}$, which is induced when they come into contact with a trace amount of water or an anion, causes them to harden and become adhesive; however, they form low viscosity liquids in the monomer state (Fig. 2) [4, 5].

CA polymers are hard and fragile. Whilst they exhibit high levels of shear strength, they are vulnerable to various types of stress, such as peeling and shock trauma. Some CA agents have had their curing strength increased by 
alkylation (Table 3). Methyl and ethyl CA, adhesives that are commonly used in both the industrial and domestic settings, are used with metallic materials because of their strength and hardness. On the other hand, methoxy ethyl and butyl CA are used with plastic or rubber because of their softness.

\section{Cyanoacrylates for medical use}

In the surgical field, CA are used to close wounds and induce hemostasis. Octyl and butyl CA are suitable for use in biological organisms because of their characteristics; i.e., they are elastic, odorless, and non-toxic after polymerization. They possess large alkyl groups, and hence, are chemically stable. NBCA, which is classified as both a butyl CA and an iso-butyl CA (IBCA), is used around the world as a medical superglue. On the other hand, ethyl CA and methyl CA have been used for medical purposes in the past, but are not used at present because their methyl/ethyl groups are very small; therefore, methyl CA and ethyl CA can easily decompose into toxic formaldehyde and alkyl cyanoacetate. However, the cyano groups of $\mathrm{CA}$, which are chemically stable, do not generate toxic cyanide-based substances, e.g., hydrocyanic acid $(\mathrm{HCN})$. Octyl CA is used to close wounds affecting the gums and repair the cornea, since it also has bactericidal and hemostatic effects. Bacterial genome experiments have demonstrated that NBCA and IBCA are mutagenic; however, they have not been proven to be carcinogenic [6]. NBCA is applied to skin wounds to achieve hemostasis. The blue type (Histoacryl blue), which contains dye (D\&C Violet No. 2), and the colorless type, which does not, are commercially available in Japan.

History and current status of intravascular treatment using NBCA

NBCA has been used in endoscopic sclerotherapy for esophageal varices and has come to be used in the treatment of bleeding disorders and arteriovenous malformations (AVM), in which the liquid is mixed with an oily contrast medium that is mainly composed of the ethyl ester of iodinated poppy-seed oil fatty acids (Lipiodol, Guerbet Japan, Tokyo, Japan) and injected into blood vessels.

In the cerebrovascular field, evidence supporting the use of NBCA has been provided by a number of clinical trials. Regarding clinical practice guidelines, NBCA-based sclerotherapy for esophageal and gastric varices has been recommended in the United States and the EU, and it is also highly recommended by level 2 evidence in Japan [7]. In the United States, it is recommended that vascular embolization should be employed before surgical resection or preoperative stereotactic radiotherapy, and it has also been recommended as a treatment for focally symptomatic or intractable infarction. In Japan, a combination of vascular embolization and surgery has been recommended for grade 3 (according to the Spetzler-Martin classification) cerebral AVM [3]. As for conditions affecting the thoracoabdominal or other regions, vascular embolization is used in the clinical setting on a daily basis in Japan and other countries, based on the findings of a number of research reports.

\section{Pharmaceutical and legal issues}

In Japan, the pharmaceutical law classifies NBCA under "orthopedic medical devices-4" as a wound dressing material for skin defects. Thus, NBCA is only approved for treating skin damage, and its intravascular administration is contraindicated. Therefore, at present, the intravascular administration of NBCA is considered to be off-label use and can only be performed at the discretion of physicians. The JSIR recommendations have been developed because whilst there are no clear legal criteria that can be used to assess the appropriateness of the off-label use of drugs and medical devices, it is considered that there is increasing clinical need for vascular embolization using NBCA [1]. Regarding drug usage and the predictability of side effects, a Japanese Supreme Court ruling called for strict compliance with the instructions listed in drug package inserts (ruling January 23, 1996) [8]. So, operators should take great care regarding the usage of medical devices and drugs. We should also highlight that the side effects relief (compensation) system that operates in Japan does not apply to health hazards that occur during the use of a treatment that is not described in a drug's package insert; therefore, sufficient consent should be obtained from the patient before treatment, particularly when complications are expected.

\section{International situation}

A product containing NBCA and contrast material (iodized poppy seed oil fatty acid ethyl ester and tantalum powder) that is used for embolizing cerebral AVM in the preoperative setting was approved for use in the United States in 2000 and has since been used in more than 10,000 cases. In addition, NBCA is licensed as an embolic material for use during endoscopic sclerotherapy for esophageal and gastric varices in Korea, the EU, Australia, Mexico, Uruguay, Morocco, and Turkey, but in Japan it was only approved for gastric variceal sclerotherapy in May 2013. Vascular embolization using NBCA has not been officially approved for use in other treatments, although a number of clinical reports about the use of NBCA during such treatments have been published in other countries [9]. 


\section{Rationale for performing vascular embolization using NBCA}

CQ1 By what mechanism does NBCA embolize vessels?

\section{Recommendation}

After coming into contact with blood plasma, NBCA starts to polymerize. As a result, blood vessels that are subjected to NBCA injection are embolized via three mechanisms: (1) cast and thrombus formation, (2) the adhesion of NBCA to the inner vascular wall, and (3) damage to the vascular endothelium.

\section{Specific comments}

NBCA polymerizes after coming into contact with ionic media in the blood via the following three mechanisms [17, 54, 58, 59, 64, 94, 95, 97, 103, 123, 130, 135, 139, 161]:

(1) Cast and thrombus formation: NBCA polymerizes to form a solid material or cast, which adjusts to the shape of the target vessel [103]. The cast fills the vascular lumen, thereby preventing blood from flowing through it $[30,102-104,117]$. As a result, the vessel becomes thrombosed. It takes just $0.087 \mathrm{~s}$ for a cast to form after NBCA comes into contact with blood plasma [132].

(2) Adhesion to the vascular wall: after being injected, the NBCA near to the tip of the catheter becomes hard and simultaneously adheres to the vascular wall. An in vitro study measuring the bonding strength achieved between the common carotid artery of a Japanese domestic white rabbit and a microcatheter after the injection of $50 \mu \mathrm{l}$ of NBCA (without any additives) found that NBCA exhibited a very strong adhesive force (7 kgf) [132]. In clinical use, NBCA is mixed with Lipiodol to adjust its polymerization time. A pathological evaluation of a mixture of NBCA and Lipiodol revealed that Lipiodol localizes in the central regions of blood vessels, whereas NBCA is deposited in the peripheral regions of blood vessels [24, 154].

(3) Damage to the vascular endothelium: Vascular endothelial damage caused by chemical or heatbased reactions results in acute necrotizing vasculitis $[23,30,39,44,60,64,90,109,115,126,139]$ and intravascular thrombus formation. Scarring and fibrosis due to vascular wall inflammatory changes enhance the embolizing effect of NBCA [60]. According to clinical histological research about the endothelial changes caused by NBCA, acute endothelial reactions accompanied by vasculitisinduced vascular necrosis developed in $40-50 \%$ of the target region, before being replaced by chronic granulomatous vasculitis, which persisted for a long time $[60,118,126]$. Although it is said that NBCA can permanently embolize a vascular lumen, animal experiments and pathological studies have revealed that vessels that have been embolized with NBCA recanalize after a certain period $[21,102,104,118$, 126, 130].

\section{Indications}

CQ2 What types of conditions is NBCA indicated for?

\section{Recommendation}

NBCA is indicated for several clinical situations: (1) cases in which a catheter cannot be advanced into the target vessel because of vascular anatomical factors or because there is a considerable risk of coil migration, (2) the embolization of long vascular segments that extend from a drainage vein to a feeding artery due to vascular malformation or an arteriovenous fistula, or (3) a hypocoagulable state (refer to CQ6) (recommendation grade C1).

Specific comments

NBCA is indicated for various conditions, including vascular conditions (aneurysms and malformations), bleeding (iatrogenic damage, trauma, and inflammation), tumors, and venous disease (varices and portal vein system disease), regardless of the location of the target lesion.

There have been many reports about the use of NBCA for treating cerebral vascular malformations, and some prospective studies have examined its use for preoperative vascular embolization $[10,38,52,53,55,57,63,86,92$, $94,96,100]$. In addition, other applications, including the use of NBCA to treat spinal vascular disease and during embolization for endoleaks that develop after endovascular aneurysm repair, have been described in recent studies [22, 34, 35, 40, 83, 108, 129, 146, 149, 152, 167].

NBCA is also used to induce embolization in cases involving bleeding caused by iatrogenic damage or trauma $[25,39,70,75,78,116,117]$. In particular, NBCA is a useful embolic material in the following situations: (a) cases in which pseudoaneurysms cannot be embolized via selective catheterization using the isolation technique; (b) embolization involving the preservation of the parent artery [56, 134, 149, 163, 167, 174, 183]; (c) cases in which coil embolization might be unsuitable because of the condition of the target vessels, e.g., those involving markedly tortuous, stenotic, or fine vessels $[54,72,87,135$, $138,165]$; (d) cases involving patients in a hypocoagulable state (refer to CQ6). Furthermore, vascular embolization with NBCA has also been reported to be useful for nasal bleeding [103, 104], hemoptysis [16, 141], and gastrointestinal bleeding.

In cancer patients, NBCA is indicated for tumor bleeding [72] and can also be used to achieve a palliative 
Table 4 Complications caused by tissue ischemia

\begin{tabular}{|c|c|c|}
\hline Complications (frequency) & Target diseases & Severity \\
\hline Brain infarction (occasionally) & $\begin{array}{l}\text { Brain AVF, pulmonary AVF, dural AVF, brain } \\
\text { tumor, CCF, pseudoaneurysm }\end{array}$ & $\begin{array}{l}\text { Mild/transient } \sim \text { death, a reported death case } \\
\text { with non-target middle cerebral artery } \\
\text { occlusion }\end{array}$ \\
\hline Spinal paralysis (n.m) & Vertebral tumor, dural AVF & Mild/transient $\sim$ severe (myeloparesis) \\
\hline $\begin{array}{l}\text { Pulmonary embolism } \\
\text { (occasionally) }\end{array}$ & $\begin{array}{l}\text { Brain AVF, pulmonary aneurysm, gastric } \\
\text { varicose vein }\end{array}$ & Asymptomatic $\sim$ severe respiratory problems \\
\hline Gastrointestinal ischemia (n.m) & $\begin{array}{l}\text { Gastrointestinal bleeding, jejunal AVM, gastric } \\
\text { varicose vein, traumatic arterial bleeding }\end{array}$ & $\begin{array}{l}\text { Moderate (ulcer with conservative } \\
\text { treatment) } \sim \text { severe (intestinal necrosis) }\end{array}$ \\
\hline Acute cholecystitis (occasionally) & Metastatic liver tumors & Moderate \\
\hline Hepatic artery occlusion (n.m) & Metastatic liver tumors & Asymptomatic but becoming untreatable \\
\hline Splenic infarction (n.m) & Splenic aneurysm & Moderate \\
\hline Renal infarction (n.m) & Renal arterial bleeding, renal AVF & Moderate \\
\hline Soft tissue injury (occasionally) & $\begin{array}{l}\text { External carotid arterial bleeding, aneurysmal } \\
\text { bone cyst, renal cell carcinoma, limb AVF }\end{array}$ & $\begin{array}{l}\text { Moderate (ischemia of lower extremity) } \\
\sim \text { severe (skin necrosis) }\end{array}$ \\
\hline Peripheral nerve injury (n.m) & $\begin{array}{l}\text { External carotid arterial bleeding, aneurysmal bone } \\
\text { cyst }\end{array}$ & Mild/transient \\
\hline
\end{tabular}

$A V F$ arterio-venous fistula, $C C F$ carotid-cavernous fistula, n.m not mentioned, occasionally: 1-10\%

therapeutic effect by improving the tumor response [32, 41, $142,145,176]$. In addition, NBCA has been indicated for arterial redistribution and hepatic arterial catheter fixation during hepatic arterial infusion chemotherapy [68, 159, $180,181]$. In the venous system, retrospective studies examining the use of NBCA for percutaneous transhepatic portal venous embolization have also been reported [19, 45, 48, 49, 77], and there have been several studies about the use of NBCA for pelvic congestion syndrome and varicoceles [27, 65, 109, 157].

\section{Complications and safety management}

CQ3 What complications are associated with vascular embolization using NBCA?

\section{Recommendation}

The complications associated with NBCA use are classified into the following five types: (1) tissue ischemia caused by vascular embolization, (2) hemorrhaging caused by increased pressure in the AVM nidus, (3) systemic and/ or local reactions, (4) catheter adhesion to the vascular wall, and (5) other rare but important complications.

Specific comments

\section{(1) Tissue ischemia (Table 4)}

Even if the target embolization range can be controlled as intended, ischemia can develop in the perfused region, depending on the collateral vessels. Moreover, it is often difficult to control the embolization range during vascular embolization using NBCA, which can cause non-target embolization. In particular, vascular embolization using
NBCA can result in the undesirable distal spread of NBCA; NBCA reflux [16, 39, 99, 101, 102, 105, 116, 117, 136, 141, 144, 145, 161]; a small amount of NBCA becoming attached to the catheter tip, causing it to be released into non-target vessels during catheter removal 10; and the induction of vital organ ischemia through collateral channels. Regarding the distal spread of NBCA, venous outflow has been detected in cases involving high-flow AVM/fistulas [18, 30, 76, 82, 137]. The NBCA injected into small and slow-flowing vessels can easily reflux around the catheter tip, which can result in the NBCA becoming attached to the catheter tip and the subsequent spread of the adhesive into the parent arteries. As for vital organ ischemia induced via collateral channels, unintended embolization of the anterior spinal artery by NBCA after its migration through the intercostal and lumber arteries has been reported [110, 144].

The following complications of NBCA have also been reported: brain infarcts $[10,29,42,46,62,74,79,84,91$, 92, 94, 96, 97, 101-107, 114, 127, 161, 172, 184], visual disturbance [29, 36, 89, 101, 102, 104, 106], ophthalmomyelitis [89], spinal paralysis [110, 150], pulmonary embolism [16, 26, 28, 30, 76, 82, 85, 93, 101, 102, 109, 141, 170], intestinal ischemia [54, 67, 68, 73, 87, 98, 99, $153,155,164,182]$, acute cholecystitis [169, 177], hepatic artery obstruction [49, 159, 181], splenic infarction [113, 167], renal infarction [39, 51, 117], soft tissue injury [88, $95,103,104,116,142,145]$, and peripheral nerve disorders [88, 142, 182].

(2) Hemorrhaging $[10,42,46,60,62,74,92-94,96$, $107,160,170]$. Draining venous obstruction of an 
Table 5 Other complications portal embolization

\begin{tabular}{llll}
\hline Complications & Target disease & Probable cause & Severity \\
\hline Brain abscess & $\begin{array}{l}\text { Cerebral } \\
\text { arteriovenous } \\
\text { malformations } \\
\text { Pseudoaneurysm } \\
\text { arising from } \\
\text { hepatic artery }\end{array}$ & $\begin{array}{c}\text { Infection via catheters, NBCA or other } \\
\text { medical apparatus }\end{array}$ & Severe \\
$\begin{array}{c}\text { Acute } \\
\text { pancreatitis }\end{array}$ & $\begin{array}{l}\text { Splenic aneurysm } \\
\text { Thrombophlebitis }\end{array}$ & $\begin{array}{c}\text { Cytokines, inflammatory response and } \\
\text { the immune response induced by } \\
\text { vascular intimal damage }\end{array}$ & Moderate \\
$\begin{array}{c}\text { Partal venous } \\
\text { thrombosis }\end{array}$ & $\begin{array}{c}\text { PTPE preceding } \\
\text { right lobectomy } \\
\text { of the liver }\end{array}$ & $\begin{array}{c}\text { NBCA reflux into the left portal branch } \\
\text { migration of the NBCA embolus }\end{array}$ & $\begin{array}{c}\text { Asymptomatic, but } \\
\text { Night lobectomy } \\
\text { was abandoned }\end{array}$ \\
\hline
\end{tabular}

AVM will result in increased intranidal pressure and can increase the risk of rupturing and hemorrhaging. The mortality rate of intracranial hemorrhaging in cases of cerebral AVM treated with vascular embolization using NBCA has been reported to range from 1.9 to $2.6 \%[10,94,96]$.

(3) Systemic and/or local reactions Various reactions have been reported to be associated with vascular embolization using NBCA, such as nausea/vomiting [68, 139, 176], high fever [48, 68, 139, 176], and regional pain [71, 95, 137, 139].

(4) Catheter adhesion to vascular walls [10, 16, 18, 39, 46, 54, 99, 101-105, 111, 116, 132, 134, 141, 154, $161,172,178,184]$. The reflux of the NBCA mixture around the catheter tip can also cause the catheter to become attached to the vascular wall. In addition, the injection of $100 \%$ NBCA can increase the risk of reflux because of its radiolucency. When a higher concentration of NBCA is used, vessel [116] or catheter rupturing $[10,172]$ occasionally occurs as the catheter becomes more firmly fixed in place.

(5) Others (Table 5)

Infections [43], brain abscesses [31], liver abscesses [19, 182], acute pancreatitis [162], thrombophlebitis [157], and portal thrombosis [48] have also been reported as complications associated with NBCA use.

CQ4 How should NBCA be used to safely embolize vessels?

\section{Recommendations}

There are various technical aspects to performing vascular embolization using NBCA safely, so the procedure should be carried out by, or with the assistance of, experienced interventional radiologists.

Operators should understand the characteristics of the target vessels prior to NBCA injection. In addition, NBCA should be mixed with contrast material to make it radiopaque, and it should be administered under X-ray fluoroscopy.

\section{Specific comments}

(1) The optimal volume, injection speed, and ratio of the NBCA-Lipiodol mixture should be determined to facilitate successful vascular embolization. Repeated contrast injection under fluoroscopy through properly placed catheters is helpful for evaluating hemodynamics, blood flow, and the diameter and volume of the target vessels $[25,47,72,80,113,123,175]$. NBCA is radiolucent, and therefore, is usually mixed with radiopaque materials such as Lipiodol [66, 91].

(2) Immediately before the injection of NBCA, the microcatheter should be thoroughly flushed with $5 \%$ nonionic dextrose solution to completely remove any ionic solutions from its lumen [64, 75, 121, 130, 140, 176]. The simultaneous perfusion of $5 \%$ dextrose through the guiding catheter during the injection of NBCA delays contact with ionic substances and prolongs the polymerization period of NBCA [123, 141].

(3) X-ray fluoroscopy, digital subtraction angiography, and biplanar road-mapping can be used to monitor procedures involving NBCA [46, 125, 161]. Operators should closely observe the progression of the NBCA during the procedure [16], and high-resolution fluoroscopic monitoring equipment can be used for this purpose [91]. Monitoring by several doctors at the same time aids precise judgments during the procedure.

(4) Several injection techniques have been reported. The continuous column method, in which the NBCA is injected slowly but continuously to allow it to form a cast inside the lumen, is the most common method and allows controlled NBCA delivery, which prevents reflux [16, 37, 46, 92, 98, 102, 137, 149]. In addition, intermittent injection with the aim of delivering drips of NBCA (the pumping method) 
and a method in which the NBCA in the catheter is pushed out with a bolus of dextrose (the sandwich technique) have also been reported [21, 46, 48, 141]. The injection should be stopped when blood flow arrests or undesirable migration of the NBCA into the distal portion of the target vessel, the spilling of NBCA along the catheter tip, severe symptoms, or other risky situations occur [13, 16, 134, 141].

(5) The catheter should be retracted immediately after the injection of NBCA to avoid inadvertent adherence to the surrounding vascular tissue $[61,116,125$, 130, 181]. Syringe aspiration is acceptable in order to induce negative pressure in the catheter to prevent NBCA migration during the removal of the catheter [46, 96]. A small amount of NBCA will remain inside the removed catheter after NBCA injection. Therefore, the successive usage of the same catheter could result in undesirable embolization. Hence, another catheter should be used for additional NBCA injections, particularly in the neurovascular field [72, 139]. Post-embolization angiography can be used to confirm the embolized region and the patency of the parent artery. Coaxial microcatheters are highly recommended for injecting NBCA because their guiding catheters preserve proximal vessels. The ability of flow-guided catheters to deliver NBCA to more distal locations would seem to be a potential safety advantage [10, 53].

(6) Super-selective embolization should be performed after the placement of a microcatheter near to the target lesion, in order to prevent the administration of an excess amount of NBCA [39, 103, 104]. Injecting small intermittent aliquots of NBCA rather than a single large bolus [71, 102] or the combined use of NBCA and other embolic materials is considered to be an effective technique for dose optimization [50, 134]. Blood flow control should be considered when NBCA migration is expected in high-flow lesions. Flow stagnation via the use of balloon catheters or wedge catheters, the combined use of vascular embolization and metallic coils or other materials, or temporary vasoconstriction via the local injection of diluted epinephrine, have been reported in such situations $[15,29,30,33,42,50,72,92,105,128,137,139,152$, $158,187]$. However, the injection of NBCA using balloon or wedge catheters can cause unexpected migration of the adhesive into a non-target area through vascular anastomoses that have not been detected on preoperative angiography, so these procedures should be carried out with great care.

(7) NBCA has more immediate and permanent effects than gelatin sponge or metallic coils. Therefore, operators should take care to only embolize the target vessels [66]. It is difficult to apply vascular embolization using NBCA to the anterior spinal, mesenteric, or other vital arteries because excessive embolization of these arteries would cause severe neurological injuries and/or organ ischemia [47, 89]. The lidocaine provocation test, a neurological examination, is useful for preventing unexpected events after vascular embolization [47, 89].

In summary, vascular embolization using NBCA should be carried out by, or under the guidance of, proficient doctors. NBCA should be administered under appropriate imaging guidance and should be mixed with contrast material to make it easier to visualize [16, 141].

CQ5 How should patients' pain be managed during vascular embolization using NBCA?

\section{Recommendation}

In general, no specific pain management strategy is required. However, in some cases it might be necessary to administer pain control drugs, such as opioid analgesics, non-pyrazolone analgesics, non-steroidal anti-inflammatory drugs (NSAIDs), or epidural anesthesia.

Specific comments

There are not enough reports about pain management for vascular embolization using NBCA; however, it can be managed with close observation alone in most cases $(64,68)$. When solid organs, such as the liver or kidneys are embolized, pain management might be necessary because it can result in acute pain. Previous reports have described the intravenous administration of pethidine and fentanyl after vascular embolization [77, 145, 176, 177, 188], and non-pyrazolone analgesics (paracetamol etc.) or NSAID have been administered for pain management during the postoperative period [16, 188].

NBCA is almost always used under general anesthesia in pediatric or cerebrovascular cases [82, 133, 142]. Some case reports have described the use of pain control drugs during the perioperative period; however, there is insufficient information about the optimal doses of pain control drugs (Table 6). Organ ischemia or patient-specific factors might be responsible for the pain experienced in some cases. Since the polymerization of NBCA involves an exothermic reaction, it can result in the destruction of the vessel wall and the perivascular tissue $[39,64,126]$. It also causes pain; however, the mechanism responsible for this is unknown.

\section{Special aspects of vascular embolization using NBCA}

CQ6 Is NBCA effective for patients in a coagulopathic state?

\section{Recommendation}

NBCA is an effective embolic material for treating patients in a coagulopathic state because its 
Table 6 Pain management for vascular embolotherapy using NBCA

\begin{tabular}{lll}
\hline Procedures (diseases) & $\begin{array}{l}\text { Embolized } \\
\text { vessels }\end{array}$ & $\begin{array}{l}\text { Drugs (administration } \\
\text { route) }\end{array}$ \\
\hline $\begin{array}{l}\text { HAE (liver metastasis from } \\
\text { insulinoma) }\end{array}$ & $\begin{array}{c}\text { Hepatic } \\
\text { artery }\end{array}$ & Morphine (iv) \\
$\begin{array}{c}\text { HAE (liver metastasis from } \\
\text { carcinoid) }\end{array}$ & $\begin{array}{c}\text { Hepatic } \\
\text { artery }\end{array}$ & Fentanyl (iv) \\
RAE (renal cell carcinoma) & Renal artery & Pethidine (iv) \\
RAE (polycystic kidney) & Renal artery & $\begin{array}{c}\text { Epidural anesthesia and } \\
\text { NSAIDs (po) }\end{array}$ \\
PTPE & Portal vein & $\begin{array}{l}\text { Fentanyl (iv) } \\
\text { PTO (gastric varices) }\end{array}$ \\
Gastric vein & $\begin{array}{l}\text { Lidocaine (iv, im) } \\
\text { ES (gastric varices) }\end{array}$ & $\begin{array}{c}\text { Gastric vein } \\
\text { Pethidine (iv) }\end{array}$ \\
BAE (hemoptysis) & Bronchial & $\begin{array}{c}\text { Non-pyrine analgesic } \\
\text { artery }\end{array}$ \\
\hline
\end{tabular}

$B A E$ bronchial artery embolization, $E S$ endoscopic sclerotherapy, $H A E$ hepatic artery embolization, $i v$ intravenous injection, im intramuscular injection, NSAIDs non-steroidal anti-inflammatory drugs, po per os, PTO percutaneous transhepatic obliteration, PTPE percutaneous transhepatic portal embolization, $R A E$ renal artery embolization

polymerization, which is required for vessel occlusion, does not depend on biogenic coagulants.

Specific comments

Gelatin sponge particles or metallic coils require biogenic coagulants in order to occlude vessels. By contrast, NBCA occludes vessels instantly by polymerizing in the blood, and hence, does not depend on biogenic coagulants. Therefore, it is considered that NBCA is more useful than other embolic materials, particularly in the setting of acute arterial hemorrhaging in coagulopathic conditions. However, it should be noted that NBCA has only been demonstrated to be useful in coagulopathic conditions in limited studies.

NBCA has been reported to be useful for clinical cases involving acute arterial hemorrhaging in coagulopathic conditions, as outlined below. In seven patients with acute lower gastrointestinal hemorrhaging and coagulopathy (elevated international normalized ratio [INR]: $\geqq 1.5$ ), the technical success rate of vascular embolization using NBCA was $100 \%$ [54]. In another report, vascular embolization with gelatin sponge for perinatal hemorrhaging in coagulopathic patients was not successful (INR $=1.55)$, but vascular embolization using NBCA was successful [66]. Furthermore, 18 coagulopathic (INR $>1.5$ or platelet count $<80000 / \mu \mathrm{L}$ ) patients who had undergone failed endoscopic embolization for non-variceal upper gastrointestinal bleeding subsequently underwent transcatheter arterial embolization with NBCA, and the clinical success rate of the procedure was $83 \%(15 / 18)$ [72]. Vascular embolization using NBCA was also demonstrated to be effective for postoperative bleeding in hemophiliacs who underwent radical prostatectomy [75]. In addition, angiographic and clinical success were achieved in four patients who had underlying coagulopathy (INR $>1.5$ or platelet count $<80000 / \mu \mathrm{L}$ ) at the time of vascular embolization using NBCA for arterial esophageal bleeding [135]. In a case-control study of acute arterial hemorrhaging, 63 arteries in 46 patients with coagulopathy (INR $>1.5$ or platelet count $<50000 / \mu \mathrm{L}$ ) were embolized with gelatin sponge particles, fibered microcoils, or NBCA. The primary hemostatic rate was significantly higher in the NBCA group $(16 / 16,100 \%)$ than in the gelatin sponge particle group $(18 / 27,67 \%)$. In addition, the operations were completed more quickly in the NBCA group $(9 \min \pm 4)$ than in the microcoils group (37 $\min \pm 19$ ) or the gelatin sponge particle group ( $25 \mathrm{~min} \pm 10)$ [185]. In a swine model-based experimental study comparing the hemostatic durability achieved by NBCA and gelatin sponge particles during transcatheter arterial embolization for acute arterial hemorrhaging in coagulopathic conditions (activated clotting time $>400 \mathrm{~s}$ ), follow-up angiography performed after the embolization procedure detected recurrent hemorrhaging in four $(80 \%)$ of the five hemorrhages that had been embolized with gelatin sponge particles, but only one ( $20 \%$ ) of the five hemorrhages that were embolized with NBCA [186].

Based on these findings, which admittedly only represent limited evidence, vascular embolization using NBCA results in greater hemostatic durability than gelatin sponge particle-based treatment, and vascular embolization can be completed most quickly using NBCA in cases of acute arterial hemorrhaging in coagulopathic conditions (e.g., INR $>1.5$ or platelet count $<50000 / \mu \mathrm{L}$ ). NBCA should be used as soon as possible to induce primary hemostasis in order to save the patient's life by preventing them from falling into an irrecoverable condition, especially in cases of life-threatening hemorrhagic shock involving severe traumatic injury or massive gastrointestinal bleeding.

CQ7 What types of contrast media can be mixed with NBCA?

\section{Recommendation}

NBCA is mixed with contrast medium prior to its intravascular administration, because it is not visible under X-ray fluoroscopy [112]. Lipiodol or another oily contrast medium is usually used for this purpose (recommendation grade $\mathrm{C} 1$ ).

\section{Specific comments}

\section{(1) Lipiodol}

Lipiodol is an oily contrast medium. Its generic name is ethyl ester of iodinated poppy-seed oil fatty acids. In Japan, it has been used during hysterosalpingography and lymphangiography. When NBCA is mixed with Lipiodol, the NBCA becomes radiopaque, and its polymerization time is increased [119, 131, 168, 182]. The intravascular 
administration of Lipiodol is not approved for use by the Japanese pharmaceutical law or in any other country except France. The Lipiodol:NBCA mixing ratio is discussed in CQ8.

\section{(2) Pantopaque}

Pantopaque (generic name: iophendylate) is another type of oily contrast medium. It has been used clinically from the 1940s, but is not currently available in Japan. It has similar characteristics to Lipiodol, and its radiopacity and its effect on the prolongation of the NBCA polymerization period are the same as those of Lipiodol [154].

\section{(3) Tantalum powder}

Tantalum powder is a rare metal powder. Tantalum has an atomic number of 73 and is referred to using the chemical symbol Ta. Tantalum powder is used to improve the visibility of NBCA, and $0.5-1.5 \mathrm{~g} / \mathrm{ml}$ of the powder are used during vascular embolization using NBCA [10, 12, 20, 82, 96, 97, 143]. NBCA and ethylene vinyl alcohol (EVAL) products containing tantalum powder are available in foreign countries.

\section{(4) Tungsten powder}

Tungsten powder is another rare metal powder. Tungsten has an atomic of 74 and is referred to using the chemical symbol W. Tungsten powder is also used to improve the visibility of NBCA; however, it is cheaper than tantalum powder. Tungsten powder reduces the $\mathrm{pH}$ of NBCA-Lipiodol mixtures and prolongs their polymerization because of its strong acidity [147]. It behaves similarly to glacial acetic acid, which is mentioned in CQ8 [156]. There have been fewer studies about tungsten powder than about tantalum powder, and its use in clinical practice is fairly limited.

CQ8 Do operators need to change the NBCA-Lipiodol mixing ratio depending on the situation?

\section{Recommendation}

It is necessary to adjust the NBCA-Lipiodol mixing ratio depending on the situation. Operators should decrease the amount of Lipiodol when attempting to embolize short segments, and should increase it when attempting to embolize long segments (recommendation grade $\mathrm{C} 1$ ).

Specific comments

NBCA is mixed with contrast materials such as Lipiodol before being used for vascular embolization because of its poor visibility under X-ray fluoroscopy. In addition to increasing the visibility of NBCA, changing the NBCALipiodol mixing ratio also affects the polymerization time $[69,122,124,148,154]$. A short polymerization time, i.e., using a small amount of Lipiodol, is suitable for occluding short blood vessel segments. After coming into contact with plasma, NBCA is completely polymerized within
Table 7 Volume\% of NBCA in NBCA/Lipiodol mixtures (modified from the literature 154)

\begin{tabular}{lc}
\hline Volume\% of NBCA & Polymerization time (s) \\
\hline $50 \%(1: 1)$ & $3.2 \pm 0.8$ \\
$33 \%(1: 2)$ & $4.7 \pm 0.5$ \\
$25 \%(1: 3)$ & $7.5 \pm 0.8$ \\
$20 \%(1: 4)$ & $11.8 \pm 1.5$ \\
\hline
\end{tabular}

Parentheses show NBCA volume: Lipiodol volume

$0.087 \mathrm{~s}$ [132]. When the amount of Lipiodol is increased, NBCA polymerization is delayed because the NBCA is prevented from coming into contact with the blood, and the mixture travels further from the catheter tip, allowing longer vessel segments to be occluded. In vitro experiments examining the relationship between the NBCA-Lipiodol dose ratio and polymerization time have found that NBCALipiodol dose ratios of $1: 1,1: 2$, and 1:3 resulted in polymerization times of $3.2,4.7$, and $7.5 \mathrm{~s}$, respectively (Table 7).

A high NBCA concentration (more than $50 \%$ ) is used for embolizing cerebral AVM because such concentrations allow short vessel segments to be occluded without the NBCA flowing out from the nidus [10, 14, 26, 27, 46, 47, $96,125]$. In addition, high concentrations of NBCA are used for dilated vessels such as varicose veins to reduce the risk of NBCA migration [27]. However, it is necessary to appropriately adjust the concentration of Lipiodol according to the diameter of the target vessel, blood flow velocity, and the distance from the catheter tip to the lesion [11, 61, $96,166]$. NBCA concentrations of $<50 \%$ are often used in other IR procedures, whereas NBCA concentrations of $12.5-25 \%$ are used to occlude entire arteries during bronchial artery embolization. Moreover, a low concentration of NBCA is used to occlude collateral arteries, e.g., to occlude the inferior phrenic artery during arterial infusion chemotherapy for liver cancer or to occlude the internal mammary artery during arterial infusion chemotherapy for advanced breast cancer [16, 180, 189].

Glacial acetic acid is not used much in clinical practice; however, it can extend the polymerization time of NBCA because it reduces the $\mathrm{pH}$ of NBCA mixtures [93].

CQ9 Is the use of combinations of NBCA and other embolic materials effective?

\section{Recommendation}

Since it is a liquid, NBCA is different from metallic coils, gelatin sponge particles, and other embolic materials, and the complementary use of combinations of embolic materials can be effective. NBCA should be used by, or under the supervision of, experienced interventional radiologists, and it should always be remembered that the installation of other embolic materials can markedly affect 
blood flow through the target vessel (recommendation grade $\mathrm{C} 1$ ).

\section{Specific statement}

Almost all kinds of embolic materials, including embolic devices such as metallic coils, vascular plugs, or detachable balloons; embolic particles such as gelatin sponges and polyvinyl alcohol; and embolic liquids such as EVAL can be used in combination with NBCA. The combined use of NBCA and other embolic materials has the advantage of preventing excessive embolization and shortening the procedure time [72, 120, 151, 171, 179].

In the cerebrovascular field, vascular embolization is mainly used to treat patients with intracranial AVM, dural arteriovenous fistulas, and traumatic carotid-cavernous fistulas. In previous papers, several embolic devices were deployed in the proximal [10, 102, 105] or distal vessels $[79,101]$ of the target lesion to reduce blood flow through the lesion and prevent the injected NBCA from migrating. In addition, other studies have described various combination methods in which the target lesion was embolized with NBCA through the main feeding artery after embolic devices such as metallic coils had been deployed in numerous small feeding arteries or draining veins, or in which multiple tiny feeding arteries were occluded with particles after the majority of the target lesion had been embolized with NBCA [20, 58, 81, 128].

In the thoracoabdominal field, embolic devices are often deployed in the distal portion of the target lesion to prevent the distal migration of NBCA [19, 34, 72, 108, 109, 149, 163], and NBCA is sometimes used in combination with other embolic materials in cases in which the target lesion was insufficiently embolized [72, 77, 81, 87, 134, 162, 180, 182]. NBCA has also been occasionally used to fix the tips of indwelling catheters in place during hepatic arterial infusion chemotherapy $[173,181]$. Operators should keep in mind that the blood flow of the target vessel can change dramatically after or during the use of other embolic materials.

In particular, it is essential to pay attention to unexpected complications, including cast spillover or migration and non-target embolization due to collateral circulation. Therefore, NBCA should be used by, or with the assistance of, proficient doctors.

\section{Conclusion}

Vascular embolization using NBCA is effective at stopping hemorrhaging and controlling vascular disease and tumors, although the use of NBCA for vascular embolization is an off-label treatment in Japan. Interventional radiologists should have a detailed knowledge of the indications for, and complications associated with, NBCA use before employing it in clinical practice.

Acknowledgments The authors thank Hirotaka Ikeda, MD; Hiroshi Kato, MD; Yukihisa Ogawa, MD; Naoaki Shibata, MD; Misako Yoshimatsu, MD (Department of Radiology, St. Marianna University School of Medicine); Hiroki Ihara, MD; Mayu Uka, MD; Koji Tomita, MD; Satoko Makimoto, MD; Yoshihisa Masaoka, MD (Department of Radiology, Okayama University Medical School); Daisaku Inoue, MD; Mina Kato, MD; Takayuki Kurinobu, MD; Takeshi Sato, MD (Department of Diagnostic and Interventional Radiology, Aichi Cancer Center Hospital); Koji Idoguchi, MD; Takuya Okada, MD; Teruaki Okuno, MD (Department of Radiology, Kobe University, Graduate School of Medicine); Atsushi Komemushi, MD; Rie Yagi, MD (Department of Radiology, Kansai Medical University); Akira Ikoma, MD (Department of Radiology, Wakayama Medical University); Natsuko Hayashi, MD (Department of Radiology, Kyoto Prefectural University of Medicine); Kentaro Shibamoto, MD (Department of Diagnostic Radiology 2, Kawasaki Hospital, Kasasaki Medical School); Shunsuke Sugawara, MD (Department of Diagnostic Radiology, National Cancer Center); Masashi Tamura, MD (Department of Diagnostic Radiology, Keio University); and Taiji Tamura, MD (Department of Radiology, Kochi Medical School) for their assistance in devising the guidelines as collaborative members of the committee, and also Kenji Takizawa, MD (Department of Radiology, St. Marianna University School of Medicine; the PGERSCC; and the CGJSIR), for his help in conducting the meetings of the guidelines committee.

Conflict of interest The authors declare that they have no conflicts of interest.

\section{References}

1. Okazaki M, Mizunuma K. The statement of embolic materials required special care in vascular use. Japan Society of Interventional radiology (homepage on the Internet). 2008 April (Accessed January 20, 2014). Available from: http://www.jsivr. jp/jimukyoku/0805kekkan.pdf (in Japanese).

2. Ito S, Ino T, Imanaka Y, Uehara N, Eguchi S, Okamoto T, et al. Part II. Process in developing practical guideline. In: Fukui T, Yoshida M, Yamaguchi N, editors. Minds Handbook in Practical Guideline 2007: Tokyo:Igakushoin;2007, p. 7-19 (in Japanese).

3. Japan Stroke Society [homepage on the Internet]. Tokyo: The stroke treatment guidelines (2009 edition), 5-1. Cerebullar arterial venous malformation (Accessed December 27, 2011). Available from: http://www.jsts.gr.jp/guideline/159_164.pdf (in Japanese).

4. Threebond (homepage on the Internet). Tokyo: Technical news 46; Cyanoacrylates (updated 1996 Jan 1; Accessed January 24, 2012). Available from: http://www.threebond.co.jp/ja/technical/ technicalnews/pdf/tech46.pdf (in Japanese).

5. KIRIYA Chemical (homepage on the Internet). Osaka: Q\&A; Q54 (Accessed December 25, 2011). Available from: http:// www.kiriya-chem.co.jp/q\&a/q54.html (in Japanese).

6. Vinters HV, Galil KA, Lundie MJ, Kaufmann JC. The histotoxicity of cyanoacrylates. A selective review. Neuroradiology. 1985;27:279-91.

7. Minds Guidelines Center (homepage on the Internet). Tokyo: Liver cirrhosis practical guidelines. The Japan Society of Gastroenterology edition; CQ3-15; is cyanoacrylate effective for hemorrhagic gastric varices? (updated 2010 April 25; Accessed 
February 1, 2014). Available from: http://minds.jcqhc.or.jp/n/ (in Japanese).

8. Iryo Governance Gakkai (homepage on the Internet). Tokyo: Assessment of the court judgment for off-label use (Accessed February 1, 2014). Available from: http://medg.jp/mt/2009/09/vol-220.html (in Japanese).

9. Ministry of Health, Labour and Welfare (homepage on the Internet). Tokyo: Singi (Accessed February 1, 2014). Available from: http://www.mhlw.go.jp/shingi/2007/07/dl/s0720-7e. pdf\#search='Trufill (in Japanese).

10. The n-BCA Trial Investigators. $N$-butyl cyanoacrylate embolization of cerebral arteriovenous malformations: results of a prospective, randomized, multi-center trial. Am J Neuroradiol. 2002;23:748-55.

11. Agid R, Terbrugge K, Rodesch G, Andersson T, Soderman M. Management strategies for anterior cranial fossa (ethmoidal) dural arteriovenous fistulas with an emphasis on endovascular treatment. J Neurosurg. 2009;110:79-84.

12. Akin ED, Perkins E, Ross IB. Surgical handling characteristics of an ethylene vinyl alcohol copolymer compared with $N$-butyl cyanoacrylate used for embolization of vessels in an arteriovenous malformation resection model in swine. J Neurosurg. 2003;98:66-70.

13. Alexander S, Korman MG, Sievert W. Cyanoacrylate in the treatment of gastric varices complicated by multiple pulmonary emboli. Intern Med J. 2006;36:462-5.

14. Andrade-Souza YM, Ramani M, Beachey DJ, Scora D, Tsao MN, Terbrugge K, et al. Liquid embolisation material reduces the delivered radiation dose: a physical experiment. Acta Neurochir (Wien). 2008;150:161-4 (discussion 164).

15. ApSimon HT, Hartley DE, Maddren L, Harper C. Embolization of small vessels with a double-lumen microballoon catheter. Part II: laboratory, animal, and histological studies. Work in progress. Radiology. 1984;151:59-64.

16. Baltacioglu F, Cimsit NC, Bostanci K, Yuksel M, Kodalli N. Transarterial microcatheter glue embolization of the bronchial artery for life-threatening hemoptysis: technical and clinical results. Eur J Radiol. 2010;73:380-4.

17. Bapuraj JR, Bilwani R, Khandelwal N, Gupta AK, Nehru VI, Suri S. Pre-operative embolization of auricular arteriovenous fistula. J Laryngol Otol. 2002;116:42-5.

18. Barr JD, Hoffman EJ, Davis BR, Edgar KA, Jacobs CR. Microcatheter adhesion of cyanoacrylates: comparison of normal butyl cyanoacrylate to 2-hexyl cyanoacrylate. JVIR. 1999;10: 165-8.

19. Bent CL, Low D, Matson MB, Renfrew I, Fotheringham T. Portal vein embolization using a nitinol plug (Amplatzer vascular plug) in combination with histoacryl glue and iodinized oil: adequate hypertrophy with a reduced risk of nontarget embolization. Cardiovasc Intervent Radiol. 2009;32:471-7.

20. Berenstein A, Song JK, Tsumoto T, Namba K, Niimi Y. Treatment of experimental aneurysms with an embolic-containing device and liquid embolic agent: feasibility and angiographic and histological results. Neurosurgery. 2009;64:367-73 (discussion 373).

21. Brothers MF, Kaufmann JC, Fox AJ, Deveikis JP. N-Butyl 2-cyanoacrylate-substitute for IBCA in interventional neuroradiology: histopathologic and polymerization time studies. Am J Neuroradiol. 1989;10:777-86.

22. Buckenham T, McKewen M, Laing A, Roake J, Lewis D, Gordon MK. Cyanoacrylate embolization of endoleaks after abdominal aortic aneurysm repair. ANZ J Surg. 2009;79:841-3.

23. Caldwell SH, Hespenheide EE, Greenwald BD, Northup PG, Patrie JT. Enbucrilate for gastric varices: extended experience in 92 patients. Aliment Pharmacol Ther. 2007;26:49-59.
24. Calvo WJ, Lieber BB, Hopkins LN, Wakhloo AK. Europium fluorescence to visualize $N$-butyl 2-cyanoacrylate in embolized vessels of an arteriovenous malformation swine model. Am $\mathbf{J}$ Neuroradiol. 2001;22:691-7.

25. Cantasdemir M, Adaletli I, Cebi D, Kantarci F, Selcuk ND, Numan F. Emergency endovascular embolization of traumatic intrarenal arterial pseudoaneurysms with $N$-butyl cyanoacrylate. Clin Radiol. 2003;58:560-5.

26. Cantasdemir M, Kantarci F, Mihmanli I, Akman C, Numan F, Islak C, Bozkurt AK. Emergency endovascular management of pulmonary artery aneurysms in Behcet's disease: report of two cases and a review of the literature. Cardiovasc Intervent Radiol. 2002;25:533-7.

27. Capasso P, Simons C, Trotteur G, Dondelinger RF, Henroteaux D, Gaspard U. Treatment of symptomatic pelvic varices by ovarian vein embolization. Cardiovasc Intervent Radiol. 1997;20(2):107-11.

28. Carapiet DA, Stevens JE. Pulmonary embolism following embolization of an arteriovenous malformation. Paediatr Anaesth. 1996;6(6):491-4.

29. Casasco A, Houdart E, Biondi A, Jhaveri HS, Herbreteau D, Aymard A, et al. Major complications of percutaneous embolization of skull-base tumors. Am J Neuroradiol. 1999;20(1):179-81.

30. Cekirge S, Oguzkurt L, Saatci I, Boyvat F, Balkanci F. Embolization of a high-output postnephrectomy aortocaval fistula with Gianturco coils and cyanoacrylate. Cardiovasc Intervent Radiol. 1996;19(1):56-8.

31. Chagla AS, Balasubramaniam S. Cerebral $N$-butyl cyanoacrylate glue-induced abscess complicating embolization. J Neurosurg. 2008;109(2):347.

32. Chaloupka JC, Mangla S, Huddle DC, Roth TC, Mitra S, Ross DA, et al. Evolving experience with direct puncture therapeutic embolization for adjunctive and palliative management of head and neck hypervascular neoplasms. Laryngoscope. 1999;109(11):1864-72.

33. Chang FC, Lirng JF, Luo CB, Teng MM, Guo WY, Chang CY. Carotid blowout treated by direct percutaneous puncture of internal carotid artery with temporary balloon occlusion. Interv Neuroradiol. 2005;11(4):349-54.

34. Chao CP, Paz-Fumagalli R, Walser EM, McKinney JM, Stockland AH, Falkensammer J, et al. Percutaneous protective coil occlusion of the proximal inferior mesenteric artery before $\mathrm{N}$-butyl cyanoacrylate embolization of type II endoleaks after endovascular repair of abdominal aortic aneurysms. JVIR. 2006;17:1827-33.

35. Choi SY, Won JY, do Lee Y, Choi D, Shim WH, Lee KH. Percutaneous transabdominal approach for the treatment of endoleaks after endovascular repair of infrarenal abdominal aortic aneurysm. Korean J Radiol. 2010;11(1):107-14.

36. Churojana A, Chiewwit P, Chuangsuwanich A, Aojanepong C, Chawalaparit $\mathrm{O}$, Suthipongchai S. Embolization of vascular malformations in head and neck regions. A single center experience. Interv Neuroradiol. 2004;10(1):37-46.

37. Cil BE, Geyik S, Akmangit I, Cekirge S, Besbas N, Balkanci F. Embolization of a giant pulmonary artery aneurysm from Behcet disease with use of cyanoacrylate and the bubble technique. JVIR. 2005;16(11):1545-9.

38. Cil BE, Vargel I, Geyik S, Peynircioglu B, Cavusoglu T. Venous vascular malformations of the craniofacial region: pre-operative embolisation with direct percutaneous puncture and $N$-butyl cyanoacrylate. Br J Radiol. 2008;81(972):935-9.

39. Cimsit NC, Baltacioglu F, Cengic I, Akpinar IN, Ilker Y, Turkeri L. Transarterial glue embolization in iatrogenic renovascular injuries. Int Urol Nephrol. 2008;40(4):875-9. 
40. Cognard C, Weill A, Tovi M, Castaings L, Rey A, Moret J. Treatment of distal aneurysms of the cerebellar arteries by intraaneurysmal injection of glue. Am J Neuroradiol. 1999;20(5):780-4.

41. Cotten A, Deramond H, Cortet B, Lejeune JP, Leclerc X, Chastanet $\mathrm{P}$, et al. Preoperative percutaneous injection of methyl methacrylate and $N$-butyl cyanoacrylate in vertebral hemangiomas. Am J Neuroradiol. 1996;17(1):137-42.

42. Cronqvist M, Wirestam R, Ramgren B, Brandt L, Romner B, Nilsson $\mathrm{O}$, et al. Endovascular treatment of intracerebral arteriovenous malformations: procedural safety, complications, and results evaluated by MR imaging, including diffusion and perfusion imaging. Am J Neuroradiol. 2006;27(1):162-76.

43. Cullen S, Alvarez H, Rodesch G, Lasjaunias P. Spinal arteriovenous shunts presenting before 2 years of age: analysis of 13 cases. Childs Nerv Syst. 2006;22(9):1103-10.

44. Cylwik B, Darewicz J, Karasewicz B. Morphometric and histological examinations of dog kidneys after embolization of the renal artery with the cyanoacrylic glue Chirurcoll-Polfa. Int Urol Nephrol. 1985;17(4):303-9.

45. de Baere T, Denys A, Paradis V. Comparison of four embolic materials for portal vein embolization: experimental study in pigs. Eur Radiol. 2009;19(6):1435-42.

46. Debrun GM, Aletich V, Ausman JI, Charbel F, Dujovny M. Embolization of the nidus of brain arteriovenous malformations with $n$-butyl cyanoacrylate. Neurosurgery. 1997;40(1):112-20 (discussion 120-1).

47. DeMeritt JS, Pile-Spellman J, Mast H, Moohan N, Lu DC, Young WL, et al. Outcome analysis of preoperative embolization with $N$-butyl cyanoacrylate in cerebral arteriovenous malformations. Am J Neuroradiol. 1995;16(9):1801-7.

48. Denys A, Lacombe C, Schneider F, Madoff DC, Doenz F, Qanadli SD, et al. Portal vein embolization with $N$-butyl cyanoacrylate before partial hepatectomy in patients with hepatocellular carcinoma and underlying cirrhosis or advanced fibrosis. JVIR. 2005;16(12):1667-74

49. Di Stefano DR, de Baere T, Denys A, Hakime A, Gorin G, Gillet $\mathrm{M}$, et al. Preoperative percutaneous portal vein embolization: evaluation of adverse events in 188 patients. Radiology. 2005;234(2):625-30.

50. Donmez H, Mavili E, Toker B, Ozturk MH, Soylu SO, Hekimoglu B. Use of a balloon and $N$-butyl-2-cyanoacrylate for treatment of arteriovenous fistula. Cardiovasc Intervent Radiol. 2008;31(Suppl 2):S111-4.

51. Dorffner R, Thurnher S, Prokesch R, Bankier A, Turetschek K, Schmidt A, et al. Embolization of iatrogenic vascular injuries of renal transplants: immediate and follow-up results. Cardiovasc Intervent Radiol. 1998;21(2):129-34.

52. Friedman DM, Verma R, Madrid M, Wisoff JH, Berenstein A. Recent improvement in outcome using transcatheter embolization techniques for neonatal aneurysmal malformations of the vein of Galen. Pediatrics. 1993;91(3):583-6.

53. Frizzel RT, Fisher WS 3rd. Cure, morbidity, and mortality associated with embolization of brain arteriovenous malformations: a review of 1246 patients in 32 series over a 35-year period. Neurosurgery. 1995;37(6):1031-9 (discussion 1039-40).

54. Frodsham A, Berkmen T, Ananian C, Fung A. Initial experience using $\mathrm{N}$-butyl cyanoacrylate for embolization of lower gastrointestinal hemorrhage. JVIR. 2009;20(10):1312-9.

55. Garcia-Monaco R, Rodesch G, Alvarez H, Iizuka Y, Hui F, Lasjaunias P. Pseudoaneurysms within ruptured intracranial arteriovenous malformations: diagnosis and early endovascular management. Am J Neuroradiol. 1993;14(2):315-21.

56. Garg A, Banait S, Babhad S, Kanchankar N, Nimade P, Panchal C. Endovascular treatment of pseudoaneurysm of the common hepatic artery with intra-aneurysmal glue ( $N$-butyl 2-cyanoacrylate) embolization. Cardiovasc Intervent Radiol. 2007;30(5):999-1002.

57. Gemmete JJ, Ansari SA, Gandhi DM. Endovascular techniques for treatment of carotid-cavernous fistula. J Neuroophthalmol. 2009;29(1):62-71.

58. Goel PK. Delayed and repeated cardiac tamponade following microleak in RCA successfully treated with intra arterial sterile glue injection. Catheter Cardiovasc Interv. 2009;73(6):797-800.

59. Gounis MJ, Lieber BB, Wakhloo AK, Siekmann R, Hopkins LN. Effect of glacial acetic acid and ethiodized oil concentration on embolization with $\mathrm{N}$-butyl 2-cyanoacrylate: an in vivo investigation. Am J Neuroradiol. 2002;23(6):938-44.

60. Gruber A, Mazal PR, Bavinzski G, Killer M, Budka H, Richling B. Repermeation of partially embolized cerebral arteriovenous malformations: a clinical, radiologic, and histologic study. Am J Neuroradiol. 1996;17(7):1323-31.

61. Guillevin R, Vallee JN, Cormier E, Lo D, Dormont D, Chiras J. $\mathrm{N}$-butyl 2-cyanoacrylate embolization of spinal dural arteriovenous fistulae: CT evaluation, technical features, and outcome prognosis in 26 cases. Am J Neuroradiol. 2005;26(4):929-35.

62. Hartmann A, Mast H, Mohr JP, Pile-Spellman J, Connolly ES, Sciacca RR, et al. Determinants of staged endovascular and surgical treatment outcome of brain arteriovenous malformations. Stroke. 2005;36(11):2431-5.

63. Heidenreich JO, Hartlieb S, Stendel R, Pietila TA, Schlattmann $\mathrm{P}$, Wolf $\mathrm{KJ}$, et al. Bleeding complications after endovascular therapy of cerebral arteriovenous malformations. Am J Neuroradiol. 2006;27(2):313-6.

64. Heye S, Maleux G, Wilms G. Pain experience during internal spermatic vein embolization for varicocele: comparison of two cyanoacrylate glues. Eur Radiol. 2006;16(1):132-6.

65. Hyodoh H, Hori M, Akiba H, Tamakawa M, Hyodoh K, Hareyama M. Peripheral vascular malformations: imaging, treatment approaches, and therapeutic issues. Radiographics. 2005;25(Suppl 1):S159-71.

66. Igarashi S, Izuchi S, Ishizuka B, Yoshimatsu M, Takizawa K. A case of pregnancy and childbirth after uterine artery embolization with a permanent embolic agent. Fertil Steril. 2011;95(1):290.e9-11. doi:10.1016/j.fertnstert.2010.04.081.

67. Ikoma A, Kawai N, Sato M, Sonomura T, Minamiguchi H, Nakai $\mathrm{M}$, et al. Ischemic effects of transcatheter arterial embolization with $N$-butyl cyanoacrylate-lipiodol on the colon in a Swine model. Cardiovasc Intervent Radiol. 2010;33(5):1009-15.

68. Inaba Y, Arai Y, Matsueda K, Takeuchi Y, Aramaki T. Right gastric artery embolization to prevent acute gastric mucosal lesions in patients undergoing repeat hepatic arterial infusion chemotherapy. JVIR. 2001;12(8):957-63.

69. Inagawa S, Isoda H, Kougo H, Isogais $S$, Sakahara H. In-vitro simulation of NBCA embolization for arteriovenous malformation. Interv Neuroradiol. 2003;9(4):351-8.

70. Chen Q, Tack C, Morcos M, Ruggiero M, Schlossberg P, Fogel $\mathrm{J}$, et al. Embolotherapy of an arterioportal fistula. Cardiovasc Intervent Radiol. 2007;30(5):1047-51.

71. Jackson JE, Mansfield AO, Allison DJ. Treatment of high-flow vascular malformations by venous embolization aided by flow occlusion techniques. Cardiovasc Intervent Radiol. 1996;19(5):323-8.

72. Jae HJ, Chung JW, Jung AY, Lee W, Park JH. Transcatheter arterial embolization of nonvariceal upper gastrointestinal bleeding with $N$-butyl cyanoacrylate. Korean J Radiol. 2007;8(1):48-56.

73. Jae HJ, Chung JW, Kim HC, So YH, Lim HG, Lee W, et al. Experimental study on acute ischemic small bowel changes induced by superselective embolization of superior mesenteric artery branches with $N$-butyl cyanoacrylate. JVIR. 2008;19(5):755-63. 
74. Jafar JJ, Davis AJ, Berenstein A, Choi IS, Kupersmith MJ. The effect of embolization with $\mathrm{N}$-butyl cyanoacrylate prior to surgical resection of cerebral arteriovenous malformations. J Neurosurg. 1993;78(1):60-9.

75. Jeong CW, Park YH, Ku JH, Kwak C, Kim HH. Minimally invasive management of postoperative bleeding after radical prostatectomy: transarterial embolization. $\mathrm{J}$ Endourol. 2010;24(9):1529-33.

76. Karagoz T, Celiker A, Cil B, Cekirge S. Transcatheter embolization of a coronary fistula originating from the left anterior descending artery by using $n$-butyl 2-cyanoacrylate. Cardiovasc Intervent Radiol. 2004;27(6):663-5.

77. Kim GC, Bae JH, Ryeom HK. Percutaneous preoperative portal vein embolization using a combination of gelatin sponge and histoacryl glue. Acta Radiol. 2009;50(10):1119-25.

78. Kim KR, Shin JH, Song HY, Ko GY, Yoon HK, Sung KB, et al. Treatment of high-flow priapism with superselective transcatheter embolization in 27 patients: a multicenter study. JVIR. 2007;18(10):1222-6.

79. Kim LJ, Albuquerque FC, Aziz-Sultan A, Spetzler RF, McDougall CG. Low morbidity associated with use of $n$-butyl cyanoacrylate liquid adhesive for preoperative transarterial embolization of central nervous system tumors. Neurosurgery. 2006;59(1):98-104.

80. Kim SH, Kwon OK, Jung CK, Kang HS, Oh CW, Han MH, et al. Endovascular treatment of ruptured aneurysms or pseudoaneurysms on the collateral vessels in patients with moyamoya disease. Neurosurgery. 2009;65(5):1000-4.

81. Kish JW, Katz MD, Marx MV, Harrell DS, Hanks SE. $N$-butyl cyanoacrylate embolization for control of acute arterial hemorrhage. JVIR. 2004;15(7):689-95.

82. Kjellin IB, Boechat MI, Vinuela F, Westra SJ, Duckwiler GR. Pulmonary emboli following therapeutic embolization of cerebral arteriovenous malformations in children. Pediatr Radiol. 2000;30(4):279-83.

83. Konas E, Canter HI, Cil B, Peynircioglu B, Karabulut E, Tuncbilek G, et al. Volumetric assessment of results of treatment of vascular malformations of the head and neck regions treated with a minimally invasive surgical technique after embolization procedure. J Craniofac Surg. 2009;20(2):402-5.

84. Krishnamoorthy T, Gupta AK, Rajan JE, Thomas B. Stroke from delayed embolization of polymerized glue following percutaneous direct injection of a carotid body tumor. Korean $\mathbf{J}$ Radiol. 2007;8(3):249-53.

85. Kwak HS, Han YM. Percutaneous transportal sclerotherapy with $\mathrm{N}$-butyl-2-cyanoacrylate for gastric varices: technique and clinical efficacy. Korean J Radiol. 2008;9(6):526-33.

86. Lasjaunias P, Garcia-Monaco R, Rodesch G, Ter Brugge K, Zerah M, Tardieu M, et al. Vein of Galen malformation. Endovascular management of 43 cases. Childs Nerv Syst. 1991;7(7):360-7.

87. Lee CW, Liu KL, Wang HP, Chen SJ, Tsang YM, Liu HM. Transcatheter arterial embolization of acute upper gastrointestinal tract bleeding with $\mathrm{N}$-butyl-2-cyanoacrylate. JVIR. 2007;18(2):209-16

88. Lee KB, Kim DI, Oh SK, Do YS, Kim KH, Kim YW. Incidence of soft tissue injury and neuropathy after embolo/sclerotherapy for congenital vascular malformation. J Vasc Surg. 2008;48(5):1286-91.

89. Lefkowitz M, Giannotta SL, Hieshima G, Higashida R, Halbach $\mathrm{V}$, Dowd C, et al. Embolization of neurosurgical lesions involving the ophthalmic artery. Neurosurgery. 1998;43(6): 1298-303.

90. Levrier O, Mekkaoui C, Rolland PH, Murphy K, Cabrol P, Moulin G, et al. Efficacy and low vascular toxicity of embolization with radical versus anionic polymerization of $n$-butyl-2- cyanoacrylate (NBCA). An experimental study in the swine. J Neuroradiol. 2003;30(2):95-102.

91. Li MH, Tan HQ, Fang C, Zhu YQ, Wang W, Wang J, et al. Trans-arterial embolisation therapy of dural carotid-cavernous fistulae using low concentration $n$-butyl-cyanoacrylate. Acta Neurochir (Wien). 2008;150(11):1149-56 (discussion 1156).

92. Li TL, Fang B, He XY, Duan CZ, Wang QJ, Zhao QP, et al. Complication analysis of 469 brain arteriovenous malformations treated with $\mathrm{N}$-butyl cyanoacrylate. Interv Neuroradiol. 2005;11(2): 141-8.

93. Lieber BB, Wakhloo AK, Siekmann R, Gounis MJ. Acute and chronic swine rete arteriovenous malformation models: effect of ethiodol and glacial acetic acid on penetration, dispersion, and injection force of $\mathrm{N}$-butyl 2-cyanoacrylate. Am J Neuroradiol. 2005;26(7):1707-14.

94. Linfante I, Wakhloo AK. Brain aneurysms and arteriovenous malformations: advancements and emerging treatments in endovascular embolization. Stroke. 2007;38(4):1411-7.

95. Liu D, Ma XC. Clinical study of embolization of arteriovenous malformation in the oral and maxillofacial region. Chin J Dent Res. 2000;3(3):63-70.

96. Liu HM, Huang YC, Wang YH. Embolization of cerebral arteriovenous malformations with $n$-butyl-2-cyanoacrylate. J Formos Med Assoc. 2000;99(12):906-13.

97. Liu HM, Huang YC, Wang YH, Tu YK. Transarterial embolisation of complex cavernous sinus dural arteriovenous fistulae with low-concentration cyanoacrylate. Neuroradiology. 2000;42(10):766-70.

98. Liu KL, Lee CW, Wang HP, Lin MT. Pre-operative localization and embolization for jejunal arteriovenous malformation with massive haemorrhage. Br J Radiol. 2007;80:e159-61.

99. Loffroy R, Rao P. Superselective transcatheter embolization to halt an arterial esophageal hemorrhage: is the use of $N$-butyl cyanoacrylate the best choice? Korean J Radiol. 2010;11(2):249-50.

100. Loh Y, Duckwiler GR. A prospective, multicenter, randomized trial of the Onyx liquid embolic system and $\mathrm{N}$-butyl cyanoacrylate embolization of cerebral arteriovenous malformations: clinical article. J Neurosurg. 2010;113(4):733-41.

101. Luo CB, Teng MM, Chang FC, Chang CY. Traumatic indirect carotid cavernous fistulas: angioarchitectures and results of transarterial embolization by liquid adhesives in 11 patients. Surg Neurol. 2009;71(2):216-22.

102. Luo CB, Teng MM, Chang FC, Chang CY. Transarterial balloon-assisted $n$-butyl-2-cyanoacrylate embolization of direct carotid cavernous fistulas. Am J Neuroradiol. 2006;27(7):1535-40.

103. Luo CB, Teng MM, Chang FC, Chang CY. Transarterial embolization of acute external carotid blowout syndrome with profuse oronasal bleeding by $N$-butyl-cyanoacrylate. Am J Emerg Med. 2006;24(6):702-8.

104. Luo CB, Teng MM, Chang FC, Chang CY. Role of CT and endovascular embolization in managing pseudoaneurysms of the internal maxillary artery. J Chin Med Assoc. 2006;69(7):310-6.

105. Luo CB, Teng MM, Yen DH, Chang FC, Lirng JF, Chang CY. Endovascular embolization of recurrent traumatic carotid-cavernous fistulas managed previously with detachable balloons. J Trauma. 2004;56(6):1214-20.

106. Lv X, Jiang C, Li Y, Yang X, Wu Z. Clinical outcomes of endovascular treatment for intracranial pial arteriovenous fistulas. World Neurosurg. 2010;73(4):385-90.

107. Lv X, Wu Z, Jiang C, Li Y, Yang X, Zhang Y, et al. Complication risk of endovascular embolization for cerebral arteriovenous malformation. Eur J Radiol. 2011;80(3):776-9.

108. Maldonado TS, Rosen RJ, Rockman CB, Adelman MA, Bajakian D, Jacobowitz GR, et al. Initial successful management of 
type I endoleak after endovascular aortic aneurysm repair with $n$-butyl cyanoacrylate adhesive. J Vasc Surg. 2003;38(4): 664-70.

109. Maleux G, Stockx L, Wilms G, Marchal G. Ovarian vein embolization for the treatment of pelvic congestion syndrome: long-term technical and clinical results. JVIR. 2000;11(7): 859-64.

110. Mascalchi M, Cosottini M, Ferrito G, Salvi F, Nencini P, Quilici N. Posterior spinal artery infarct. Am J Neuroradiol. 1998; 19(2):361-3.

111. Mathis JM, Evans AJ, DeNardo AJ, Kennett K, Crandall JR, Jensen ME, et al. Hydrophilic coatings diminish adhesion of glue to catheter: an in vitro simulation of NBCA embolization. Am J Neuroradiol. 1997;18(6):1087-91.

112. Matos GF, Hammadeh R, Francois C, McCarthy R, Leya F. Controlled myocardial infarction induced by intracoronary injection of $n$-butyl cyanoacrylatein dogs: a feasibility study. Catheter Cardiovasc Interv. 2005;66(2):244-53.

113. Matsumoto K, Ushijima Y, Tajima T, Nishie A, Hirakawa M, Ishigami $\mathrm{K}$, et al. Recanalization of splenic artery aneurysm after transcatheter arterial embolization using $N$-butyl cyanoacrylate. Cardiovasc Intervent Radiol. 2010;33(1):187-90.

114. Matsumoto T, Yamagami T, Kato T, Hirota T, Yoshimatsu R, Nishimura T. Transcatheter arterial embolisation of a ruptured pseudoaneurysm of the lingual artery with $n$-butyl cyanoacrylate. $\mathrm{Br} \mathrm{J}$ Radiol. 2007;80(950):e54-7. doi:10.1259/bjr/ 61848822.

115. Matsuo T, Yanai H, Sugiu K, Tominaga S, Kimata Y. Orbital exenteration after transarterial embolization in a patient with Wyburn-Mason syndrome: pathological findings. Jpn J Ophthalmol. 2008;52(4):308-13.

116. Mavili E, Donmez H, Ozcan N, Akcali Y. Endovascular treatment of lower limb penetrating arterial traumas. Cardiovasc Intervent Radiol. 2007;30(6):1124-9.

117. Mavili E, Donmez H, Ozcan N, Sipahioglu M, Demirtas A. Transarterial embolization for renal arterial bleeding. Diagn Interv Radiol. 2009;15(2):143-7.

118. Mazal PR, Stichenwirth M, Gruber A, Sulzbacher I, Hainfellner JA. Tissue reactions induced by different embolising agents in cerebral arteriovenous malformations: a histopathological follow-up. Pathology. 2006;38(1):28-32.

119. McConnell KA, Tjoumakaris SI, Allen J, Shapiro M, Bescke T, Jabbour PM, Rosenwasser RH, Nelson PK. Neuroendovascular management of dural arteriovenous malformations. Neurosurg Clin N Am. 2009;20(4):431-9.

120. Meisel HJ, Mansmann U, Alvarez H, Rodesch G, Brock M, Lasjaunias P. Effect of partial targeted $N$-butyl-cyano-acrylate embolization in brain AVM. Acta Neurochir (Wien). 2002;144(9):879-87 (discussion 888).

121. Miyachi S, Negoro M, Okamoto T, Kobayashi T, Kida Y, Tanaka T, Yoshida J. Embolisation of cerebral arteriovenous malformations to assure successful subsequent radiosurgery. J Clin Neurosci. 2000;7(Supp 1):182-5.

122. Moo LR, Murphy KJ, Gailloud P, Tesoro M, Hart J. Tailored cognitive testing with provocative amobarbital injection preceding AVM embolization. Am J Neuroradiol. 2002;23(3): 416-21.

123. Moore C, Murphy K, Gailloud P. Improved distal distribution of $n$-butyl cyanoacrylate glue by simultaneous injection of dextrose $5 \%$ through the guiding catheter: technical note. Neuroradiology. 2006;48(5):327-32.

124. Morihiro $Y$, Harada $K$, Kato S, Ishihara H, Shirao S, Nakayama $\mathrm{H}$, et al. Delayed parenchymal hemorrhage following successful embolization of brainstem arteriovenous malformation. Case report. Neurol Med Chir (Tokyo). 2010;50(8):661-4.
125. Mounayer C, Hammami N, Piotin M, Spelle L, Benndorf G, Kessler I, Moret J. Nidal embolization of brain arteriovenous malformations using Onyx in 94 patients. Am J Neuroradiol. 2007;28(3):518-23.

126. Natarajan SK, Born D, Ghodke B, Britz GW, Sekhar LN. Histopathological changes in brain arteriovenous malformations after embolization using Onyx or $N$-butyl cyanoacrylate. Laboratory investigation. J Neurosurg. 2009;111(1):105-13.

127. Nelson PK, Russell SM, Woo HH, Alastra AJ, Vidovich DV. Use of a wedged microcatheter for curative transarterial embolization of complex intracranial dural arteriovenous fistulas: indications, endovascular technique, and outcome in 21 patients. J Neurosurg. 2003;98(3):498-506.

128. Niimi Y, Berenstein A, Fernandez PM, Brisman JL, Song JK. Pediatric nonvertebral paraspinal arteriovenous fistulas along the segmental nerve: clinical, imaging, and therapeutic considerations. J Neurosurg. 2005;103(Suppl 2):156-62.

129. Niimi Y, Berenstein A, Setton A, Neophytides A. Embolization of spinal dural arteriovenous fistulae: results and follow-up. Neurosurgery. 1997;40(4):675-82 (discussion 682-683).

130. Numan F, Cakirer S, Islak C, Ogut G, Kadioglu A, Cayan S, Tellaloglu S. Posttraumatic high-flow priapism treated by $\mathrm{N}$ butyl-cyanoacrylate embolization. Cardiovasc Intervent Radiol. 1996;19(4):278-80.

131. Ohta T, Gomi M, Oowaki H, Ishikawa M. Chronic venous congestion following embolization of spinal dural arteriovenous fistula. J Neurosurg Spine. 2008;9(2):186-90.

132. Oowaki H, Matsuda S, Sakai N, Ohta T, Iwata H, Sadato A, et al. Non-adhesive cyanoacrylate as an embolic material for endovascular neurosurgery. Biomaterials. 2000;21(10):1039-46.

133. Oran I, Parildar M, Derbent A. Ventricular/paraventricular small arteriovenous malformations: role of embolisation with cyanoacrylate. Neuroradiology. 2005;47(4):287-94.

134. Parildar M, Oran I, Memis A. Embolization of visceral pseudoaneurysms with platinum coils and $\mathrm{N}$-butyl cyanoacrylate. Abdom Imaging. 2003;28(1):36-40.

135. Park JH, Kim HC, Chung JW, Jae HJ, Park JH. Transcatheter arterial embolization of arterial esophageal bleeding with the use of $N$-butyl cyanoacrylate. Korean J Radiol. 2009;10(4):361-5.

136. Paulsen RD, Steinberg GK, Norbash AM, Marcellus ML, Lopez JR, Marks MP. Embolization of rolandic cortex arteriovenous malformations. Neurosurgery. 1999;44(3):479-84 (discussion 484-486).

137. Pelz DM, Lownie SP, Fox AJ, Hutton LC. Symptomatic pulmonary complications from liquid acrylate embolization of brain arteriovenous malformations. Am J Neuroradiol. 1995;16(1):19-26.

138. Peskircioglu L, Tekin I, Boyvat F, Karabulut A, Ozkardes H. Embolization of the deep dorsal vein for the treatment of erectile impotence due to veno-occlusive dysfunction. J Urol. 2000;163(2):472-5.

139. Pollak JS, White RI Jr. The use of cyanoacrylate adhesives in peripheral embolization. JVIR. 2001;12(8):907-13.

140. Ramond MJ, Valla D, Mosnier JF, Degott C, Bernuau J, Rueff B, Benhamou JP. Successful endoscopic obturation of gastric varices with butyl cyanoacrylate. Hepatology. 1989;10(4):488-93.

141. Razavi MK, Murphy K. Embolization of bronchial arteries with $\mathrm{N}$-butyl cyanoacrylate for management of massive hemoptysis: a technical review. Tech Vasc Interv Radiol. 2007;10(4):276-82.

142. Rossi G, Rimondi E, Bartalena T, Gerardi A, Alberghini M, Staals EL, et al. Selective arterial embolization of 36 aneurysmal bone cysts of the skeleton with $N$-2-butyl cyanoacrylate. Skeletal Radiol. 2010;39(2):161-7.

143. Sadato A, Wakhloo AK, Hopkins LN. Effects of a mixture of a low concentration of n-butylcyanoacrylate and ethiodol on tissue reactions and the permanence of arterial occlusion after 
embolization. Neurosurgery. 2000;47(5):1197-203 (discussion 1204-1205)

144. Schirmer CM, Malek AM, Kwan ES, Hoit DA, Weller SJ. Preoperative embolization of hypervascular spinal metastases using percutaneous direct injection with $n$-butyl cyanoacrylate: technical case report. Neurosurgery. 2006;59(2):e431-2 (author reply e431-432).

145. Serafin Z, Karolkiewicz M, Strzesniewski P, Lasek W, Bryczkowski M, Wolski Z. Palliative percutaneous kidney embolization with enbucrilate in patients with renal cell carcinoma: safety and symptom control. Med Sci Monit. 2007;13(Suppl 1):98-104

146. Sherif C, Gruber A, Bavinzski G, Standhardt H, Widhalm G, Gibson D, et al. Long-term outcome of a multidisciplinary concept of spinal dural arteriovenous fistulae treatment. Neuroradiology. 2008;50(1):67-74.

147. Shimohira M, Ogino H, Sasaki S, Ishikawa K, Koyama M, Watanabe K, et al. Transcatheter arterial embolization for segmental arterial mediolysis. J Endovasc Ther. 2008;15(4):493-7.

148. Shin TB, Yoon SK, Lee KN, Choi JS, Kim YH, Sung CG, et al. The role of pulmonary CT angiography and selective pulmonary angiography in endovascular management of pulmonary artery pseudoaneurysms associated with infectious lung diseases. JVIR. 2007;18(7):882-7.

149. Song HH, Won YD, Kim YJ. Transcatheter $N$-butyl cyanoacrylate embolization of pseudoaneurysms. JVIR. 2010;21(10): $1508-11$.

150. Song JK, Gobin YP, Duckwiler GR, Murayama Y, Frazee JG, Martin NA, et al. $N$-butyl 2-cyanoacrylate embolization of spinal dural arteriovenous fistulae. Am $\mathrm{J}$ Neuroradiol. 2001;22(1):40-7.

151. Starke RM, Komotar RJ, Otten ML, Hahn DK, Fischer LE, Hwang BY, et al. Adjuvant embolization with $N$-butyl cyanoacrylate in the treatment of cerebral arteriovenous malformations: outcomes, complications, and predictors of neurologic deficits. Stroke. 2009;40(8):2783-90.

152. Stavropoulos SW, Kim H, Clark TW, Fairman RM, Velazquez O, Carpenter JP. Embolization of type 2 endoleaks after endovascular repair of abdominal aortic aneurysms with use of cyanoacrylate with or without coils. JVIR. 2005;16(6):857-61.

153. Stavropoulos SW, Park J, Fairman R, Carpenter J. Type 2 endoleak embolization comparison: translumbar embolization versus modified transarterial embolization. JVIR. 2009; 20(10):1299-302.

154. Stoesslein F, Ditscherlein G, Romaniuk PA. Experimental studies on new liquid embolization mixtures (histoacryl-lipiodol, histoacryl-panthopaque). Cardiovasc Intervent Radiol. 1982;5(5):264-7.

155. Suh DC, Kim KS, Lim SM, Shi HB, Choi CG, Lee HK, et al. Technical feasibility of embolizing aneurysms with glue $(N$ butyl 2-cyanoacrylate): experimental study in rabbits. Am J Neuroradiol. 2003;24(8):1532-9.

156. Suh DC, Shi HB, Park SS, Lee MS, Choi HY. Change of spontaneous reaction of glue and lipiodol mixture during embolization after the addition of tungsten powder: in vitro study. Am J Neuroradiol. 2000;21(7):1277-9.

157. Sze DY, Kao JS, Frisoli JK, McCallum SW, Kennedy WA 2nd, Razavi MK. Persistent and recurrent postsurgical varicoceles: venographic anatomy and treatment with $N$-butyl cyanoacrylate embolization. JVIR. 2008;19(4):539-45.

158. Tan YM, Goh KL, Kamarulzaman A, Tan PS, Ranjeev P, Salem $\mathrm{O}$, et al. Multiple systemic embolisms with septicemia after gastric variceal obliteration with cyanoacrylate. Gastrointest Endosc. 2002;55(2):276-8.

159. Tanaka T, Arai Y, Inaba Y, Matsueda K, Aramaki T, Takeuchi $\mathrm{Y}$, et al. Radiologic placement of side-hole catheter with tip fixation for hepatic arterial infusion chemotherapy. JVIR. 2003;14(1):63-8.

160. Taylor CL, Dutton K, Rappard G, Pride GL, Replogle R, Purdy $\mathrm{PD}$, et al. Complications of preoperative embolization of cerebral arteriovenous malformations. J Neurosurg. 2004;100(5):810-2.

161. Teng MM, Chen CC, Lirng JF, Chen SS, Lee LS, Chang T. $N$ butyl-2-cyanoacrylate for embolisation of carotid aneurysm. Neuroradiology. 1994;36(2):144-7.

162. Tokuda T, Tanigawa N, Kariya S, Komemushi A, Nomura M, Suzuki S, et al. Pancreatitis after transcatheter embolization of a splenic aneurysm. Jpn J Radiol. 2010;28(3):239-42.

163. Tokuda T, Tanigawa N, Shomura Y, Kariya S, Kojima H, Komemushi A, et al. Transcatheter embolization for peripheral pseudoaneurysms with $n$-butyl cyanoacrylate. Minim Invasive Ther Allied Technol. 2009;18(6):361-5.

164. Toyoda H, Kumada T, Sone Y, Isogai M, Kaneoka Y. Lateonset colonic occlusion after emergent selective embolization of sigmoid artery with $N$-butyl cyanoacrylate for life-threatening traumatic bleeding. JVIR. 2009;20(10):1376-9.

165. Toyoda H, Nakano S, Kumada T, Takeda I, Sugiyama K, Osada $\mathrm{T}$, et al. Estimation of usefulness of $N$-butyl-2-cyanoacrylatelipiodol mixture in transcatheter arterial embolization for urgent control of life-threatening massive bleeding from gastric or duodenal ulcer. J Gastroenterol Hepatol. 1996;11(3):252-8.

166. Tranbahuy $\mathrm{P}$, Borsik M, Herman $\mathrm{P}$, Wassef $\mathrm{M}$, Casasco A. Direct intratumoral embolization of juvenile angiofibroma. Am J Otolaryngol. 1994;15(6):429-35.

167. Tulsyan N, Kashyap VS, Greenberg RK, Sarac TP, Clair DG, Pierce G, et al. The endovascular management of visceral artery aneurysms and pseudoaneurysms. $J$ Vasc Surg. 2007;45(2):276-83 (discussion 283).

168. Turner WW Jr, Ellman BA. Transhepatic embolization in patients with acute variceal hemorrhage. Am J Surg. 1981;142(6):731-4.

169. Velat GJ, Reavey-Cantwell JF, Sistrom C, Smullen D, Fautheree GL, Whiting J, et al. Comparison of $N$-butyl cyanoacrylate and onyx for the embolization of intracranial arteriovenous malformations: analysis of fluoroscopy and procedure times. Neurosurgery. 2008;63(1 Suppl 1):ONS73-8. doi:10.1227/01.neu. 0000335015.83616.12 (discussion ONS78-80).

170. Venkatesh SK, Kumar S, Baijal SS, Phadke RV, Kathuria MK, Gujral RB. Endovascular management of pseudoaneurysms of the splenic artery: experience with six patients. Australas Radiol. 2005;49(4):283-8.

171. Wakhloo AK, Lieber BB, Siekmann R, Eber DJ, Gounis MJ. Acute and chronic swine rete arteriovenous malformation models: hemodynamics and vascular remodeling. AJNR. 2005;26(7):1702-6.

172. Wakhloo AK, Perlow A, Linfante I, Sandhu JS, Cameron J, Troffkin $\mathrm{N}$, et al. Transvenous $n$-butyl-cyanoacrylate infusion for complex dural carotid cavernous fistulas: technical considerations and clinical outcome. Am J Neuroradiol. 2005;26(8):1888-97.

173. Waltman AC, Luers PR, Athanasoulis CA, Warshaw AL. Massive arterial hemorrhage in patients with pancreatitis. Complementary roles of surgery and transcatheter occlusive techniques. Arch Surg. 1986;121(4):439-43.

174. Wang YC, Wong HF, Yeh YS. Intracranial pial arteriovenous fistulas with single-vein drainage Report of three cases and review of the literature. J Neurosurg. 2004;100(2 Suppl Pediatrics):201-5.

175. Wikholm G. Occlusion of cerebral arteriovenous malformations with $\mathrm{N}$-butyl cyano-acrylate is permanent. Am J Neuroradiol. 1995;16(3):479-82.

176. Winkelbauer FW, Niederle B, Pietschmann F, Thurnher S, Wildling R, Prokesch R, et al. Hepatic artery embolotherapy of 
hepatic metastases from carcinoid tumors: value of using a mixture of cyanoacrylate and ethiodized oil. AJR Am J Roentgenol. 1995;165(2):323-7.

177. Winkelbauer FW, Nierderle B, Graf O, Prokesch R, Thurnher S, Wildling $\mathrm{R}$, et al. Malignant insulinoma: permanent hepatic artery embolization of liver metastases-preliminary results. Cardiovasc Intervent Radiol. 1995;18(6):353-9.

178. Wong SH, Tan J, Yeo TT, Ong PL, Hui F. Surgical excision of intracranial arteriovenous malformations after preoperative embolisation with $N$-butylcyanoacrylate. Ann Acad Med Singapore. 1997;26(4):475-80.

179. Wu Z, Wang C, Yang X, Sun Y, Zhang Y, Li Y, et al. Endovascular embolization of traumatic carotid cavernous fistulas. Chin Med J (Engl). 1999;112(5):433-7.

180. Yamagami T, Kato T, Iida S, Tanaka O, Nishimura T. Value of transcatheter arterial embolization with coils and $n$-butyl cyanoacrylate for long-term hepatic arterial infusion chemotherapy. Radiology. 2004;230(3):792-802.

181. Yamagami T, Nakamura T, Yamazaki T, Iida S, Kato T, Nishimura T. Catheter-tip fixation of a percutaneously implanted port-catheter system to prevent dislocation. Eur Radiol. 2002;12(2):443-9.

182. Yamakado K, Nakatsuka A, Tanaka N, Takano K, Matsumura K, Takeda K. Transcatheter arterial embolization of ruptured pseudoaneurysms with coils and $n$-butyl cyanoacrylate. JVIR. 2000;11(1):66-72.

183. Yokouchi T, Iwabuchi S, Tomiyama A, Samejima H, Ogata N, Goto K. Embolization of scalp AVF. Interv Neuroradiol. 1999;5(Suppl 1):121-6.

184. Yu SC, Chan MS, Lam JM, Tam PH, Poon WS. Complete obliteration of intracranial arteriovenous malformation with endovascular cyanoacrylate embolization: initial success and rate of permanent cure. Am J Neuroradiol. 2004;25(7):1139-43.

185. Yonemitsu T, Kawai N, Sato M, Tanihata H, Takasaka I, Nakai $\mathrm{M}$, et al. Evaluation of transcatheter arterial embolization with gelatin sponge particles, microcoils, and $n$-butyl cyanoacrylate for acute arterial bleeding in a coagulopathic condition. JVIR. 2009;20(9):1176-87.

186. Yonemitsu T, Kawai N, Sato M, Sonomura T, Takasaka I, Nakai $\mathrm{M}$, et al. Comparison of hemostatic durability between $N$-Butyl cyanoacrylate and gelatin sponge particles in transcatheter arterial embolization for acute arterial hemorrhage in a coagulopathic condition in a Swine model. Cardiovasc Intervent Radiol. 2010;33(6):1192-7.

187. Morishita H, Yamagami T, Takeuchi Y, Matsumoto T, Asai S, Masui $\mathrm{K}$, et al. A new flow control technique using diluted epinephrine in the $n$-butyl-2-cyanoacrylate embolization of visceral artery pseudoaneurysms secondary to chronic pancreatitis. CVIR. 2012;35:932-7.

188. Morishita H, Yamagami T, Takeuchi Y, matsumoto T, Asai S, Nakanouchi T, et al. Use of $\mathrm{N}$-butyl-2-cyanoacrylate for transcatheter arterial embolization of renal arteries in patients with polycystic kidney disease. JVIR. 2011;22:1631-3.

189. Takizawa K, Shimamoto H, Ogawa Y, Yoshimatsu M, Yagihashi K, Nakajima Y, et al. Development of a new subclavian arterial infusion chemotherapy method for locally or recurrent advanced breast cancer using an implanted catheter-port system after redistribution of arterial tumor supply. CVIR. 2009;32:1059-66. 